\title{
Evolution of Modularity Literature A 25-year Bibliometric Analysis
}

\section{Frandsen, Thomas}

\author{
Document Version \\ Accepted author manuscript
}

Published in:

International Journal of Operations and Production Management

DOI:

10.1108/IJOPM-06-2015-0366

Publication date:

2017

\section{License}

Unspecified

Citation for published version (APA):

Frandsen, T. (2017). Evolution of Modularity Literature: A 25-year Bibliometric Analysis. International Journal of Operations and Production Management, 37(6), 703-747. https://doi.org/10.1108/lJOPM-06-2015-0366

Link to publication in CBS Research Portal

\section{General rights}

Copyright and moral rights for the publications made accessible in the public portal are retained by the authors and/or other copyright owners and it is a condition of accessing publications that users recognise and abide by the legal requirements associated with these rights.

Take down policy

If you believe that this document breaches copyright please contact us (research.lib@cbs.dk) providing details, and we will remove access to the work immediately and investigate your claim. 


\section{Evolution of Modularity Literature: A 25-year Bibliometric Analysis}

\section{Thomas Frandsen}

Journal article (Accepted manuscript)

CITE: Frandsen, T. (2017). Evolution of Modularity Literature: A 25-year Bibliometric Analysis. International Journal of Operations and Production Management, 37(6), 703-747. 001: 10.1108/IJOPM-06-2015-0366

This article is @ E Emerald Publishing Limited 2017 and permission has been granted for this version to appear here: https://research.cbs.dk/en/publications/evolution-of-modularity-literature-a-25-yearbibliometric-analysi.

Emerald does not grant permission for this article to be further copied/distributed or hosted elsewhere without the express permission from Emerald Group Publishing Limited.

Uploaded to Research@CBS: December २018 


\title{
Evolution of modularity literature: a 25-year bibliometric analysis
}

\author{
Thomas Frandsen(tfr.om@cbs.dk) \\ Assistant Professor \\ Copenhagen Business School \\ Solbjerg Plads 3 \\ DK-2000 Frederiksberg \\ Denmark \\ Tlf.: +4538152930
}

\begin{abstract}
Purpose - The purpose of this paper is to review and analyze the modularity literature to identify established and emerging perspectives.

Design/methodology/approach - A systematic literature search and review was conducted through the use of bibliometrics and network analysis. The analysis identified structure within the literature, which revealed how the research area evolved between 1990 and 2015. Based on this search, the paper establishes the basis for analyzing the structure of modularity literature.

Findings - Factors were identified within the literature, demonstrating how it has evolved from a primary focus on the modularity of products to a broader view of the applicability of modularity. Within the last decade, numerous research areas have emerged within the broader area of modularity. Through core-periphery analysis, eight emerging sub-research areas are identified, of which one is the study of modularity in the context of services.

Research limitations/implications - Although bibliographic methods is limited as it is based on common citations within the field it enables systematic analysis and the identification of structure within an emergent field of research. Such analysis have implications by for a
\end{abstract}


growing and inter-disciplinary field like modularty by providing overview and suggesting future directions.

Originality/value - This paper contributes by conducting a systematic review based on the citation structure within modularity and identifies established and emerging areas of research on modularity.

Keywords - Modularity, Bibliometrics, Architecture

Paper type - Research paper

\section{Introduction}

Managers are faced with the challenge of navigating an increasingly complex world, in which customers with individual needs and preferences expect providers to customize their solutions. Moreover, the boundaries between products and services are blurring and business models are changing rapidly, which both impact the complexity and dynamics of delivery systems even further. In this changing context, the concept of modularity increasingly finds application within and across organizations. The literature has grown significantly and the multifaceted nature of the concept of modularity is becoming ever more clearer. There appears to be a need to establish an overview of this growing literature and identify its future directions. In other fields of research, bibliometric analysis has proved to be a strong technique for providing such an overview in a systematic and objective manner and one which has uncovered latent structures and identified emerging areas (i.e. Pilkington and Chai, 2008)

This paper surveys the extant modularity literature from a managerial perspective and seeks to identify its intellectual structure and developments. Several researchers have contributed to the field by reviewing different aspects of the modularity literature, with several reviews taking the perspective of modularity in management studies (Campagnolo and Camuffo, 2010), product modularity (Salvador, 2007), modularity research themes (Bask et al., 2010), service decomposition and modularizing services (Eissens-van der Laan et al., 2016), concurrent engineering (Fixson, 2007), and dominant design (Murman and Frenken, 2006). 
Other studies have focused on particular aspects of modularity, such as manufacturing operations (Doran and Hill, 2009), supply chain management (Gunasekaran and Ngai, 2005; Reichhard and Holweg, 2007), interface definitions (Parslov and Mortensen, 2015), product platforms (Zhang, 2015; Chen and Liu, 2005), manufacturing scheduling systems (Framinan and Ruiz, 2010), product architecture and supply chain design (Pashaei and Olhager, 2015; Yassine and Wissmann, 2007) and research and development (R\&D) outsourcing (Hsuan and Mahnke, 2011).

To a varying degree, these literature reviews were based on a delimited search strategy; identifying relevant literature, selecting and coding articles based on perceived relevance and content, and analyzing and synthesizing based on a reading of the selected articles in light of the authors' knowledge of the field. A strength of these studies is that they provide an overview of a field of research and point to its evolution and future research areas. The weakness lies in the reliance on interpretation and coding to identify structures in the literature. An alternative approach is the one taken in this study, in which bibliometric analysis is used as the basis for identifying the structure of the citation patterns, instead of the subjective coding of content. Although this type of analysis has been conducted in related fields within operations management (Pilkington and Fitzgerald, 2006; Pilkington and Meredith, 2009), no co-citation-based analysis of modularity has been identified. As modularity has become an increasingly interdisciplinary field, as suggested in the previous reviews, the notion is discussed from many perspectives and at different levels. Given that co-citation patterns have repeatedly been shown to systematically identify structures within fields of literature, it is curious that this has not been applied to the widening modularity literature. The purpose of this paper, therefore, is to review the management literature on modularity in an attempt to identify the central positions, based on a systematic analysis of citation patterns. Through the use of bibliographic information, this paper advances our understanding by applying network analysis to systematically identify the intellectual structures and development of the literature. Specifically, this paper has four aims: first, to identify the structure within the modularity literature by highlighting seminal contributions, as well as to emphasize the apparent structure of the way in which articles on modularity co- 
cited; second, to show how the field has evolved from 1990 to 2015; third, to systematically identify emerging research areas within the modularity literature; and fourth, to locate the emerging field of service modularity in the wider modularity literature.

To achieve these aims, this paper identifies and systematically analyzes and reviews the modularity literature produced during the period 1990 to 2015. The paper employs co-citation analysis to identify structures and the evolution of the literature, whilst the network analytical technique of core-periphery analysis is used to identify emerging research areas. The review reveals how this area has developed during recent years and how it is receiving increasing attention. New topics within modularity have emerged, including the study of service modularity (Voss and Hsuan, 2009; Bask et al., 2010; Pekkarinen and Ulkuniemi, 2008).

Section 2 discusses the notion of modularity and provides an explanation. In Section 3, the research methodology is presented, while Section 4 presents the findings from the analysis. Section 5 provides conclusions and points to future directions for research on modularity, in general and specifically by reference to service modularity.

\section{Modularity and its meaning: an explanation}

\subsection{Defining modularity}

Modularity is a method of designing a structure to reduce its complexity. Although complexity is clearly related to the number of different elements of a structure, the nature of the interdependencies between those elements and the way in which they interface has profound implications for structural complexity. This complexity may be handled by reducing the number of units and by grouping these units into subsystems. The primary driver is to reduce the interdependencies between elements across subsystems (Langlois, 2002). Thus, modularity can be defined by referring to relations between the module's elements and the relations of those elements with elements of other modules. The word "module" has been used variously but is suggested in Webster's Revised Unabridged Dictionary to originate from the Latin word modulus, which means "a small measure." A contemporary meaning, which is consistent with the Webster characterization, can be found in Wiktionary: a "module" is "a 
self-contained component of a system, often interchangeable, which has a well-defined interface to the other components."

Modularity has been studied in a wide range of disciplines, from mathematics to psychology. With the aim of studying modularity in relation to management, this paper follows Baldwin and Clark (2000) in defining modularity. A module is consequently characterized by an interdependence between the elements of the modules and a high degree of independence across the modules (Baldwin and Clark, 2000). The loose coupling of components occurs by defining an architecture that specifies the interfaces between the components of the architecture (Sanchez and Mahoney, 1996). Thus, the degree of modularity depends on the components used, their interfaces, the character of the coupling, and the opportunity for replacement (Mikkola, 2006).

Modularity provides numerous design advantages (Ethiraj and Levinthal, 2004; Sanchez and Mahoney, 1996; Baldwin and Clark, 2000). Modular construction improves opportunities for rapid changes through splitting and substituting modules (Baldwin and Clark, 2000). Modular product architectures and the opportunity to "mix and match" modules can lead to strategic flexibility, with the opportunity for greater product variation, as well as a higher and more frequent number of product introductions (Sanchez and Mahoney, 1996; Worren et al., 2002). Moreover, reusing the same module in several structures provides scale benefits (Baldwin and Clark, 2000) and the economic advantage of substitution (Garud and Kumaraswamy, 1995). Product modularity is closely related to product configuration strategies such as mass customization and postponement (Mikkola and Skjøtt-Larsen, 2004). Reducing the interdependence between modules can reduce asset specificity (Baldwin, 2008), increase the opportunity for outsourcing (Schilling and Steensma, 2001), and, in general, reduce the cost of coordination between components (Langlois, 2002). In addition, modular constructions are more robust to changes in the environment (Pil and Cohen, 2006).

Modularity research has been undertaken from multiple perspectives, as can be seen in the table in Appendix I, which lists the 20 articles on modularity most frequently cited by other papers on modularity. Modularity is relevant not only to product design but also to processes 
and organizations (Sanchez and Mahoney, 1996; Baldwin and Clark, 2000) and, increasingly, to services (Voss and Hsuan, 2009; de Blok et al., 2010). MacCormack et al. (2001) argue that in turbulent environments, the development process must be flexible, so that it may respond to "new or changing information during a development project" (p. 134). Turbulence requires a modular design that can be adapted not only after its development but also during its design (Buganza and Verganti, 2006). Regarding service design, Verganti and Buganza (2006) point to a modular technological architecture as one factor that can increase the lifecycle flexibility of services. However, modularity is not an either/or choice and should be seen as a trade-off between the advantages and the disadvantages in the specific context (Ethiraj and Levinthal, 2004) in which modularity is associated, with the cost of achieving a modular design over an integrated design (Langlois, 2002). Pursuing modularity too far may even be associated with a penalty (Ethiraj and Levinthal, 2004).

\subsection{Theoretical underpinnings of modularity research}

Although modularity has recently gained substantial attention, the topic has been discussed in the literature for many years, and modular principles have been applied since the building of the Pyramids (Starr, 2010). However, since the mid-20 ${ }^{\text {th }}$ century, many seminal contributions have considered different aspects of modularity in various contexts. Starr (1965) made an early contribution within operations management, proposing modular production to increase the variety of product offerings in order to meet market requirements without sacrificing efficiency in production. Whereas Starr specifically addressed manufacturing operations, Simon (1962) turned to complex systems in general. He conceptualized architectures as hierarchical systems and argued that the ability to decompose systems hierarchically is the primary means of managing complexity. Within design, Alexander (1964), in his "notes on the synthesis of form," explains how the challenge of design is not usually optimizing a set of individual requirements but designing interdependent subsystems that simultaneously meet requirements and create a functioning whole (the synthesis of form), a more complex task. Thompson (1967), an organizational theorist who realized the importance of uncertainty and the need for adaptability in organizational systems early, pointed to the nature of interdependencies and how they differ within and across 
organizations. Although Thompson did not explicitly discuss modularity, he proposed that organizational design is crucially related to the grouping of components by referring to the nature of their interdependencies with other components within the organization. $\mathrm{He}$ distinguished between pooled, sequential, and reciprocal interdependencies and argued that there are different ways of achieving coordination, the appropriateness depending on the nature of the interdependencies (Thompson, 1967). Building on Thompson's insight that organizations simultaneously attempt to operate as closed systems in some ways and as open systems in others, Weick (1976) proposed loose coupling as a method for capturing the nuances of organizations that are not caught by "words like connection, link, or interdependence" (p. 3). Similar to Simon's notion of nearly decomposable systems, loose coupling embraces the idea that most systems are neither entirely decoupled nor fully coupled and instead are nearly decomposable or hierarchical. In the software engineering literature, Parnas (1972) offered early insights into the value of information hiding, by suggesting that a module should be "characterized by its information of a design decision which it hides from all others. Its interface or definition was chosen to reveal as little as possible about its inner workings" (p. 1056). Furthermore, in relation to processes, Parnas suggested that when software systems are designed, the basis for decomposition into modules should be by reference to design decisions instead of steps in the process. Looking at task problem-solving interdependencies, von Hippel proposed that they can be managed in two ways: by partitioning the tasks to reduce interdependencies between them or by reducing the cost of problem-solving across task boundaries. Partitioning tasks has three requirements: the tasks most likely to be sources of new information must be anticipated, which other tasks will be affected by such information must be predicted, and these insights should be incorporated into the tasks' specification (von Hippel, 1990).

\section{INSERT TABLE I ABOUT HERE}

Although the growing academic interest in modularity is increasingly specific about the empirical objects of modularity and theoretical understandings of causal mechanisms, several seminal contributions are typically drawn upon for the key principles that underpin 
discussions of modularity. These principles, summarized in Table I, are related to different areas of research and bring the principle of modularity into different domains that are relevant to management. Once primarily related to physical systems such as products, modularity is now discussed in relation to organizations, information systems, innovation, and, importantly, service architectures. This discussion has important implications in the present study for the search criteria used to source articles on modularity. Modularity is a multifaceted concept with managerial implications in multiple fields. The search criteria used in this paper were designed to capture the literature that addresses these managerial concerns, while avoiding an excessive number of irrelevant source articles.

\section{Methodology and data for bibliographic analysis}

In this section, an extensive review of the modularity literature is provided, followed by a detailed examination, in Section 4, of the findings. The selection criteria are described and the methodology for analyzing the literature using bibliographic data is presented.

\subsection{Inclusion and exclusion criteria for the literature search}

To establish a base population of items within modularity, a search was performed on the ISI Web of Science using the Science Citation Index and the Social Science Citation Index. To identify the current state of the research on modularity, as well as to uncover developments in the literature, the period from 1990 to 2015 was chosen. Although scholars made seminal contributions to complexity and decomposition before this period (c.f. Simon, 1962; Alexander, 1964; Star, 1965), the 1990s marked the formation of a stream of modularity literature. Furthermore, generally fewer articles were published and/or indexed in the Web of Science prior to 1990, which led to fewer available data. When the specified search criteria were used for pre-1990 literature, 18 records were returned, of which only two contain cited references and abstracts.

The Web of Science field "topic" was chosen as an inclusion criterion as it evaluates not only the title or author-supplied keywords of an article but also abstracts and keyword plus. The search was performed using the Boolean search terms "modularity," "modular AND design," and "modular AND architecture". To narrow the search to items focused on 
modularity and management, the Web of Science field "subject area" was used as an exclusion criterion, and items not classified within one or more of the subject areas "management," "operations research and management science," "economics," and "business" were omitted. The search was narrowed by the field "type" to include only "articles," "proceedings papers," and "reviews". In total, 888 source articles were identified, which are specified in Table II.

\section{INSERT TABLE II ABOUT HERE}

Based on a reading of the abstracts, titles, and keywords of these articles, those that were not relevant and those in which modularity was treated only peripherally were excluded. Articles were mainly excluded because modularity was mentioned as a characteristic of a developed model or in relation to mathematical algorithms. The abstract screening resulted in 636 articles.

\subsection{Limitations of the search criteria}

Identifying the group of articles that best reflects the topic under investigation is critical to any literature review, and different strategies can be chosen. However, any search, whether subjective or mechanical, runs the risk of excluding articles that should have been included and conversely including articles that are not relevant. Thus, the search strategy and screening process have limitations and may be problematic. First, the Web of Science contains only selected journals, which implies that the inclusion criteria may result in the omission of journals including relevant articles. Second, the terms chosen to perform the search may have unintended consequences; for instance, using the broad term "modul*" resulted in numerous irrelevant items. However, the terms used widened the search without considerably increasing the number of irrelevant items.

To mitigate the shortcomings of the mechanical nature of the search, many choices were made. First, using "topic" as the main search criterion will return results including item titles and the criteria within the "abstract," "author supplied keywords," and the "keyword plus." 
"Keyword plus" identifies articles that touch upon modularity without a specific reference in the title, abstract, or keyword. Keyword plus indexes are based on the titles of an article's cited references. Articles that are relevant to the search that do not use any of the search terms may, therefore, still be included, provided that the references include articles with the search terms in their titles. As shown in Table II, 159 articles were identified, based on one of the three combinations of search terms, which would not have been identified otherwise.

\subsection{Improvements to data quality}

Based on this literature search, a dataset consisting of 636 relevant articles, along with 32,691 individual references (links between an article and the cited reference) was constructed. Each reference was treated as an edge between two vertices (the citing article and the cited article, respectively). To identify the individual vertices in the dataset, unique reference identification was created. The data quality of the Web of Science is generally high, especially for items recently added to the index. However, several inconsistencies caused by errors in abbreviations of author names, page numbers, and journal names were identified. Inconsistencies imply that the same contribution is not identified as such but is represented as two vertices in the dataset. To eliminate inconsistencies and accommodate redundancies, corrections were made by identifying similar, but not identical, items and evaluating whether the similarity was caused by an error in the dataset. A total of 7,630 corrections were made to the dataset, which eliminated redundancies among the most frequently cited references. Thus, the dataset was suitable for bibliographic and network analysis. Bibliometric analysis has been critiqued for including negative citations and self-references (Pilkington and Meredith, 2009). The measures explained below do not express consensus among articles but rather topical proximity, which negative citations still indicate. However, extensive self-referencing can be a source of bias, particularly in citation analysis. Consequently, we have systematically identified 1,671 instances in which the first author of a cited reference is also an author of the citing article. Such self-references are excluded from the citation analysis, considered in subsection 4.1 below, in order to avoid self-inflated citation counts. For bibliographic coupling and co-citation analysis, studies that "deliberately ignore self-citations are unfairly penalizing scholars who tend to publish in new or unfashionable fields in which few others are working, 
as well as those who have built careers through systematic exploration of a particular topic with which their name is associated" (Borgman and Furner, 2002, p. 16). Findings are not significantly impacted by self-referencing, but disregarding such references may penalize articles such as those of Sanchez and Mahoney (1996), which Borgman and Furner (2002) caution against.

\subsection{Bibliographic coupling and co-citations}

Bibliographic coupling of a directed network indicates the proximity of two vertices based on the number of other vertices to which the two vertices point toward. In a citation network, this method can indicate the proximity of two articles, as they share a similar reference pattern. A related proximity measure is co-citation, which measures the number of vertices that point toward both vertices $i$ and $j$. In citation analysis, two articles that are similar to other articles typically cite both (Newman, 2010). Based on the citations dataset, an asymmetric adjacency matrix A of references was constructed with Aij 1, where article $j$ cites article $i$, and 0 otherwise. As articles that have similar referencing patterns are likely to be related, this matrix was used to identify the structure in the group of articles. A bibliographic coupling matrix $\mathrm{B}$ was calculated as $\mathrm{A}^{\mathrm{T}} \mathrm{A}$ with $\mathrm{B}_{\mathrm{ij}}$ being the number of references shared by articles $i$ and $j$. Similarly, a bibliometric co-citation matrix $C$ was calculated as $\mathrm{AA}^{\mathrm{T}}$ with $\mathrm{C}_{\mathrm{ij}}$ being the number of references citing both articles $i$ and $j$. The metrics for bibliographic coupling can be calculated as either the number of identical references (Newman, 2010) or the Pearson correlation coefficients of the cited references (Pilkington and Meredith, 2009). A high number of identical references or a high correlation coefficient indicates the proximity of two articles, whereas low or no shared references or negative correlation coefficients indicate distance between the articles' content. To avoid negative values, the correlation coefficients were normalized to values between 0 and 1 . Based on the correlation coefficients, a network graph can be drawn, as shown in Figure 3. 


\section{INSERT FIGURE 1 ABOUT HERE}

Figure 1 illustrates how the citation patterns of the contributions about modularity help identify two types of structures within the literature. The bibliographic coupling measure identifies groupings of articles with similar citation patterns, which is used to indicate proximity between the content of the articles. Gavetti et al. (2005) and Ethiraj and Levinthal (2004a) display tight bibliographic coupling, as they include numerous references to the literature on complex adaptive systems. Likewise, Salvador et al. (2002) and Jacobs et al. (2011) display tight coupling, due to the many common references to literature on production systems and mass customization. However, a high number of co-occurrences among cited references indicates proximity in the ideas of the articles. Thus, the same dataset indicates that Kauffman (1993) and Levinthal (1997) are related as an element in the intellectual structure underpinning the modularity literature. Studying the content of these two contributions reveals that they are concerned with organizational search and adaptation in complex systems. The two measures thus provide indications of proximity, which can be used to identify a structure within the literature. A directed network graph based on a subset of the dataset can illustrate the causes of these proximity measures.

\section{INSERT FIGURE 2 ABOUT HERE}

The directed network graph in Figure 2 shows the referencing relationships between eight articles, which were found through the literature search and commonly referenced sources. As the figure illustrates, the articles have several references in common, notably Simon (1962), Baldwin and Clark (2000), Sanchez and Mahoney (1996), and Ulrich and Eppinger (1995). However, the figure also shows that the articles fall into two groups, each of which uses a distinct set of common references. Although the edges of the graph contain information only about the direction of the reference, these common references indicate that the articles in the two groups have conceptual proximity. Bibliographic coupling is used to estimate this proximity. Similar citation patterns in two articles thus result in a higher measure 
of bibliographic coupling. Based on this measure, the network graph in Figure 3 illustrates the relationships between the articles identified in the literature search. Links in this graph indicate bibliographic coupling between two articles; denser links indicate higher bibliographic coupling.

\section{Findings}

In the analysis of the bibliometric data from the modularity literature explained above, the source articles have been divided in three periods, corresponding first to the early period (the 1990s), then the formation period (the 2000s), and, finally, the recent period (20102015). This section provides a general overview of the modularity literature, its evolution and emerging research areas. Sub-section 4.1. present the findings which emerged from analyzing the journals cited by the modularity literature. Sub-section 4.2. identifies the structure of the modularity literature through an analysis based on bibliometric coupling. Sub-section 4.3 identifies the intellectual structure behind the modularity literature by undertaking co-citation analysis on the core literature. In sub-section 4.4, the evolution of subfields within the modularity literature is mapped through the use of co-citation analysis on the periphery literature. Sub-section 4.5 explores in more detail the emerging field of service modularity identified in the previous section.

\subsection{Identifying structure in the literature by seminal contributions and most cited journals}

Citation analysis can be a useful way to identify the importance attributed to particular journals and individual contributions. Table III shows the journals most frequently cited by the reviewed papers on modularity, during the three periods and in total. The Strategic Management Journal (SMJ) is the most frequently cited journal for the entire period. Although 364 papers in SMJ are cited, approximately $29 \%$ of the citations made to this journal are to five of the 20 papers most frequently cited by other papers on modularity (Appendix I and II). Management Science (5\% of citations to Ethiraj and Levinthal, 2004) and Research Policy (21\% of citations to Ulrich, 1995) are second and third overall. Although there is some stability in the pattern of citations to journals throughout the period, the referencing patterns have changed. For example, the Harvard Business Review was the most frequently cited 
journal in the 1990s. However, many operations and innovation management journals entered the list in the 2000s and became more frequently cited during the recent period. Specifically, the 275 references made to articles in the International Journal of Operations and Production Management (IOPM) make it the $10^{\text {th }}$ most cited journal by articles on modularity published in the period 2010 to 2015. This change could reflect the observation, suggested in Figure 6 and Table III, that modularity has entered several specific research domains and supplemented strategic management.

\section{INSERT TABLE III ABOUT HERE}

\subsection{Identifying structure in the modularity literature through co-citing patterns}

Bibliographic coupling is based on the premise that similarity in referencing patterns can be an indication of topical proximity between source articles and can be used to visualize and analyze structure within the referencing literature. This section explores the referencing patterns of the modularity literature using bibliographic coupling and factor analysis. Figure 3 shows a network visualization of the literature and indicates the factors identified. Nodes in the network represent citing articles, while edges represent bibliographic coupling, i.e. the number of references shared by two nodes.

\section{INSERT FIGURE 3 ABOUT HERE}

Figure 3 was created using UciNet software (Borgatti et al., 2002) for network analysis and was visualized using NetDraw (Borgatti, 2002). To identify structure within the modularity literature, it was necessary to reduce the density of the network diagram. Consequently, among the 636 source articles, only the 261 articles which have been cited at least once by other scholars have been included. Furthermore, we followed the procedure outlined by Vogel and Güttel (2012), in order to set a threshold for the number of shared references and the number of articles to which this applied. To achieve clarity without sacrificing detail, only the 68 articles sharing at least 14 references with at least two other 
source articles were included. Figure 3 shows that while there are similarities in referencing patterns, differences also exist, indicating that different views on modularity exist in the literature. To complement the network analysis and explore these differences, a factor analysis was conducted, using SPSS 22.0.

\section{INSERT TABLE IV ABOUT HERE}

The factor analysis was performed as a principal component analysis using Varimax rotation. The number of components was determined based on the evaluation of a scree plot, resulting in nine components, accounting for $37.7 \%$ of the variance explained. The factor analysis involved an analysis of the correlation matrix, based on the 68 source articles as outlined above. The analysis then identified factors among the source articles on modularity and resulted in an acceptable Kaiser-Meyer-Olkin measure of sampling adequacy of 0.768. Bartlett's test of sphericity was significant at a $\mathrm{p}$ value of less than 0.001 . These results indicate that the correlations in the dataset are appropriate for factor analysis.

The rotated component matrix was inspected to identify the characteristics of each factor, based on the individual article in the component. To interpret these factors, the titles, abstracts, keywords and content of the articles in each group were investigated to identify commonalities. Individual references in each group were used to identify the causes of the high bibliographical coupling of the articles. The labeling of factors was based on the interpretation of multiple researchers, following a process in which authors were provided with initial labels, following which two researchers independently formulated labels for each of the factors and noted down factors presenting difficulties. The labels were subsequently organized and are as set out in Table IV. Articles in different factors typically draw on different strands of research, and modularity tends to be defined and discussed in relation to different seminal articles on modularity. That is, the group organizational search and adaption tends to define modularity by reference to Simon (1962) on near decomposability and Baldwin and Clark (2000), whereas the group product architecture and platforms tend to define modularity by referring to Henderson and Clark (1990) and Ulrich (1995). The 68 
source articles can be illustrated based on the groupings identified through the bibliographic analysis of the content. Modularity and its development are discussed in the following section.

\section{INSERT FIGURE 4 ABOUT HERE}

Figure 4 shows the nine factors identified through factor analysis and the distribution of the 68 articles over time. Two factors were initiated in the 1990s, while most of the remaining factors were formed during the 2000s. Two of the factors only have references published in the most recent period. A benefit of bibliometric coupling analysis is, that it allows for the inclusion of recent articles. Consequently the analysis can suggest developments in the literature as seen above. Further consideration of emerging areas of research follows in subsection 4.4 .

INSERT FIGURE 5 ABOUT HERE 
Figure 5 shows four snapshots of the modularity literature and indicates that research increases significantly towards the end of the middle period and during the beginning of the recent period. This growth seems to stem from a growing awareness of modularity and its relevance within different areas of research. In particular, modularity seems to be increasingly applied in domains other than product architecture, most notably service architecture and organizations.

\subsection{Exploring the evolution of the field of modularity from 1990 to 2015}

In co-citation analysis, proximity between referenced articles is estimated based on how frequently source articles cite two references. It can therefore be a way of identifying intellectual structures on which the field draws. By carrying out co-citation analysis for the entire period, as well as for separate periods within this study, it is possible to explore the evolution of the field. Figure 6 is based on a co-citation analysis of the bibliometric data for the 150 most frequently co-cited articles, showing only core references and lines represented by normalized Pearson correlation coefficients above 0.6. The figure reveals that the modularity literature draws on a range of sources. Distinct groupings of research with similar referencing patterns can also be identified.

\section{INSERT FIGURE 6 ABOUT HERE}

As the figure shows, identifying distinct research areas in the core literature is difficult, in part perhaps because most of the source articles tend to define modularity by referring to the same group of seminal contributions. In Appendix I, the 20 source articles that are most frequently cited by other source articles are listed. As the table in Appendix I suggests, there are nuances in the way modularity is defined in these seminal contributions, which stem from the different perspectives of the articles. Much of the modularity literature has focused on product architecture and how modular design is related to strategic outcomes. A key interest has been how modularity helps organizations achieve strategic flexibility and economics of substitution. Although part of the early literature focused on an organization's strategic advantages, another early interest was how modularity is related to the development of 
capabilities within organizations and, more recently, across organizations. Figures 7 to 9 show developments in the core modularity literature, with Sanchez and Mahoney (1996), Baldwin and Clark (1997, 2000), and Ulrich (1995) becoming focal points of reference.

INSERT FIGURE 7 ABOUT HERE

INSERT FIGURE 8 ABOUT HERE

INSERT FIGURE 9 ABOUT HERE 


\subsection{Identify emerging research areas within the modularity literature}

As co-citation analysis is based on how frequently articles are co-cited, it generally gives more prominence to frequently cited references. While it is beneficial to attribute prominence to highly cited papers when identifying the intellectual roots of a field, the time it takes to generate citations implies that emerging research may feature less prominently. Here, coreperiphery analysis is beneficial, as it identifies and removes the dense core of co-citations illustrated in Figures 6 to 9, which represent the established mainstream references. Removing the core leaves the co-citation patterns that are still strong enough to reflect commonality of thought but have not yet become part of the primary reference set. Again, these peripheral citations are represented by lines based on normalized Pearson correlation coefficients, showing only lines with values above 0.75 . The periphery network can identify potential emerging research areas (Pilkington and Chai, 2008). As suggested by Figures 10 to 13, the modularity literature has increasingly been linked to the study of organizations, in the sense that product and service modularity influences the structure of organizations, is a structural property of the organizations themselves, and affects decision making within organizations. Moreover, the literature seems to have evolved through the emergence of increasingly more specific knowledge domains, which have extended the study of modularity from product modularity to organizations and supply chains, as well as various levels of analysis from components to an architectural level.

\section{INSERT FIGURE 10 ABOUT HERE}

\section{INSERT FIGURE 11 ABOUT HERE}

INSERT FIGURE 12 ABOUT HERE

\section{INSERT FIGURE 13 ABOUT HERE}

Figure 13 suggests that there is a continuing opportunity for studies on modularity by identifying eight specific emerging areas of research. In addition to the use of case based 
research, these include studying the effects of modularity on organizations and supply chains (i.e. Cheng et al., 2014) and reconfiguration and dynamic capabilities (i.e. Vickery et al., 2015), as well as vertical integration and disintegration (i.e. Helfat, 2015). Similarly, the strong relation between modularity and innovation seems to suggest that modularity is finding a place in the literature on open innovation (i.e. Baldwin and von Hippel, 2011; Jaspers and van den Ende, 2010), developing across boundaries (i.e. Hong and Hartley, 2011) and optimizing design of complex systems (i.e. Baldwin et al., 2014). Interestingly, the three citations in the center of Figure 13 (Voss and Hsuan, 2009; Bask et al., 2010; Pekkarinen and Ulkuniemi, 2008) all focus on service modularity. Given the aim of this paper, this emerging area receives further attention in the following section.

\subsection{Locating the emerging field of service modularity in the wider modularity literature}

While service modularity has been identified as one of eight emerging research areas within the modularity literature, this section explores this subfield in more detail, in order to locate it within the wider modularity literature. Voss and Hsuan (2009) emphasize that service design must be considered from the perspective of service architecture, which implies a concern with decomposition and understanding the nature of interfaces and components (Voss and Hsuan, 2009). Pekkarinen and Ulkuniemi (2008) suggest a platform-based approach for developing services, whereas Bask et al. (2010) propose, by reference to a logistic service provider case, a framework for understanding service modularity in relation to business models and modular processes.

\section{INSERT TABLE V ABOUT HERE}

Table V sets out the 13 source articles whose co-citations cause service modularity to appear as an emerging research area in the periphery analysis of the recent period. They can be considered a starting point for understanding this emerging research area. De Blok et al. (2010) suggest that modularity has practical implications for service design and in designing services, modularity is a key aspect to consider. Within this literature, modularity has been 
studied in diverse contexts such as healthcare (de Blok et al., 2010, 2013, 2014; Vahatalo and Kallio, 2015), logistic services (Rajahonka, 2013; Lin and Pekkarinen 2011; Cabigiosu et al., 2015), and manufacturing (Carlborg and Kindström, 2014; Hellstrom, 2014). This development resonates well with the general realization of the growing economic importance of services, as well as the technological developments that fuse services in traditional manufacturing contexts (Carlborg and Kindström, 2014). Although most studies rely on case study research, Hofman and Meijerink (2015) employ a qualitative method to investigate platform thinking within services. The authors analyze human resource management (HRM) but address service modularity only indirectly, by classifying activities in terms of the service delivery mode, differentiation in needs, and HRM service value.

\section{INSERT TABLE VI ABOUT HERE}

Table VI show the journals from which citations are made to the three key source articles. Although citations are made from dedicated service management journals, the majority are from within industrial marketing and operations management journals, and the International Journal of Operations and Production Management (IJOPM) in particular. There may be several reasons, but the strong domain knowledge of product modularity, derived from decades of operations management research, seems to provide a strong foundation for understanding issues that are most important in service management. Product manufacturers have responded to customer requests for customization by modularizing product architectures and developing mass customization capabilities. In services, personalization has, possibly, been the preferred response to the same challenge. The advances in information technology and the growing scale of service operations imply that this response creates excessive complexity that service providers need to address, with modularity a strong candidate solution. 


\section{Discussion and future research directions}

\subsection{Summary of contributions}

The modularity literature has grown significantly, and many approaches to studying modularity have emerged. Network analytical techniques based on bibliographic data have shown how this literature has developed into distinct research areas. Once primarily related to the strategic benefits of product modularity, the literature has increasingly turned to other aspects of modularity, including organizations, information technology, manufacturing capabilities, and innovation. The use of modularity as a key concept in different areas has resulted in the development of individual groupings that touch upon different aspects of modularity and focus on its varying consequences. The original perception of modularity in terms of product architecture with strategic relevance has changed to operational capabilities and production strategies, innovation processes, organizational structure, and industry evolution.

Furthermore, the literature has evolved from predominantly theoretical frameworks and propositions to empirical investigations that use various research methods. Many studies have thus empirically tested proposed relationships, while others have sought to understand modularization at the level of individual firms and their inter-organizational relationships. Using the network analytical approach to investigate the bibliographic data has proven to be a strong technique for revealing the development of research approaches on a topic of importance across disciplines. Although prior research applied similar techniques to the study of the development of research disciplines, this paper contributes by investigating the development of an increasingly noteworthy topic and demonstrating how the analytical approach can improve our understanding of the development of critical areas. This insight can aid research and practice and create an overview of the complexity of an evolving literature.

This paper seeks to add to the knowledge of the modularity literature gained through previous systematic literature reviews (Campagnolo and Camuffo, 2010; Salvador, 2007; Bask et al., 2010; Fixson, 2007). While the observation that the modularity literature has 
expanded into several domains confirms those of previous studies, the findings from this paper contribute to the literature in a number of ways. First, the paper identifies distinct research groups within the modularity literature. Although they resonate with previous reviews, these groups are based on the citation patterns in the literature, which are more objective than the subjective evaluations used to identify similar structures in previous reviews. Second, the co-citation analysis of three specific time periods shows how the field has evolved from a primary emphasis on product modularity to address modularity in a range of other domains. Specifically, new sub-research of modularity in relation to topics such as organizational search and adaptation, mass customization, component commonality and the use of specific methods of conceptualizing modularity (such as the design structure matrix (DSM)), whilst particular research methods, such as case study research, have emerged. Third, the paper identifies eight emerging sub-research areas (see Figure 13) based on a periphery analysis of the recent period (2010-2015), one of which is service modularity. Finally, by analyzing the source articles, which resulted in service modularity appearing as an emerging area, this paper discusses several potentially fruitful future directions for the modularity literature.

\subsection{Future directions in modularity research}

The findings suggest several avenues for future investigation. Modularity has become a diverse field of research, for which the objects of study have been widened and the levels of analysis extended. This broadened scope implies that modularity is now studied at the industry, supply chain, firm, platform, product/service, and component levels. Based on a periphery analysis of the recent period (2010-2015), eight sub-research areas were identified, suggesting emerging areas of modularity research. In addition to case research, these include studying modularity in relation to organizations and supply chains (i.e. Cheng et al., 2014), dynamic capabilities (i.e. Vickery et al., 2015), as well as vertical integration and disintegration (i.e. Helfat, 2015), open innovation (i.e. Baldwin and von Hippel, 2011), how

modularity impacts development across boundaries (i.e. Hong and Hartley, 2011) and optimizing the design of complex systems (i.e. Baldwin et al., 2014). 
The final emerging research area is service modularity, which is identified in the analysis due to the frequent co-citations of Voss and Hsuan (2009), Bask et al. (2010), and Pekkarinen and Ulkuniemi (2008). This observation is in line with recent reviews suggesting that modularity seems to be growing in importance within the design and management of services (Bask et al., 2010; Eissens-van der Laan et al., 2016). It also resonates with the research priorities identified by Ostrom et al. (2015) through a survey of service researchers. For the area of service networks and systems, they point to "service architecture and modularization in the context of value networks" as an important research priority.

This paper contributes by systematically identifying service modularity as an emerging area through core-periphery analysis. By analyzing the same citation data used in the periphery analysis, the paper identifies the source articles whose co-citations are the basis for considering service modularity as an emerging area. The data suggests that these co-citing references are a starting point for understanding the evolution of this emerging area. A brief review of these source articles showed that numerous applications of service modularity have already been explored. However, given the early state of this area of research, the predominant research design has been exploratory, using qualitative research methods within either single or a few case contexts. An interesting exception is Hofman and Meijerink (2015), who employed a quantitative research method to study platform thinking in services. However, no direct operationalization of the service modularity construct as a scale for survey research was found in the literature. Consequently, there seems to be potential for future studies to synthesize and operationalize the knowledge gained through more exploratory studies, to further the understanding of service modularity. In addition to reviewing the source articles co-citing papers on service modularity, an analysis of the journals in which the papers are published reveals that service modularity primarily emanates from the operations management domain, with IJOPM being a journal that has devoted particular attention to service modularity.

Finally, the strong presence of service modularity within the industrial marketing and operations management journals may be a result of the growing importance of service modularity among manufacturing firms (Carlborg and Kindström, 2014; Hellstrom, 2014). 
An increasingly important emerging area within the wider service literature is servitization, which focuses on how manufacturers tackle the challenges of implementing service-based business models (Pilkington et al., 2015). Service modularity is important in understanding how such firms can overcome the complexities of heterogeneous customer needs for advanced services, which would be a fruitful avenue for future research.

\subsection{Limitations of the present study and suggestions for extending bibliometric analysis}

While bibliometric analysis is a useful method for identifying structure within fields of research by using patterns of co-citation (Pilkington and Chai, 2008; Pilkington and Meredith, 2009), it also comes with its own limitations. Specifically, it is a retrospective form of analysis, entirely based on the co-citation patterns of already published research. As the publication process is often lengthy and takes months, sometimes years, the data collected from the ISI Web of Science and analyzed in this paper is, by its nature, lagging behind the most contemporary developments in the actual research settings. Furthermore, although bibliometric analysis relies on more objective data in the form of journal citations and replicable methods such as the co-citation analysis, it lacks the detailed understanding gained from systematically reading and interpreting the contributions within a field. Consequently, bibliometric analysis is not a substitute for systematic literature reviews and the interpretation of results still requires revisiting the literature to understand the meanings of the analysis. The use of bibliographic coupling has only recently gained attention in bibliometric studies within management. However as suggested by Zupic and Cater (2015) it has the benefit of including more recent publications in the analysis, thereby complementing co-citation analysis to enable timid identification of emerging areas of research. A potential area for future research could be to combine a systematic literature review of source articles, to add additional codes to the data. Such hybrid analysis would allow for a richer dataset by reference to which refined bibliometric analysis along multiple dimensions could subsequently be performed. Such classifications could include the object of modularity, as well as the level of analysis and empirical methods employed. 


\section{References}

Aas, T.H. and Pedersen, P.E. (2013), "The usefulness of componentization for specialized public service providers", Managing Service Quality, Vol. 23 No. 6, pp. 513-532.

Abernathy, W.J. and Utterback, J.M. (1978), "Patterns of industrial innovation", Technology review, Vol. 64, pp. 254228.

Alexander, C. (1964), Notes on the Synthesis of Form, Cambridge: Harvard.

Anderson, P. and Tushman, M.L. (1990), "Technological discontinuities and dominant designs: A cyclical model of technological change", Administrative science quarterly, Vol. 35, pp. 604-633.

Antonio, K.W.L., Yam, R.C.M. and Tang, E. (2007), "The impacts of product modularity on competitive capabilities and performance: an empirical study", International Journal of Production Economics, Vol. 105 No. 1, pp. 1-20.

Argyres, N. and Bigelow, L. (2010), "Innovation, modularity, and vertical deintegration: evidence from the early US auto industry",Organization Science, Vol. 21 No. 4, pp. 842-853.

Baker, K. R., Magazine, M. J. and Nuttle, H. L. (1986), "The effect of commonality on safety stock in a simple inventory model", Management Science, Vol. 32 No. 8, pp. 982-988.

Baldwin, C. Y. (2008), "Where do transactions come from? Modularity, transactions, and the boundaries of firms", Industrial and Corporate Change, Vol. 17 No. 1, pp. 155-195.

Baldwin, C. Y. and Clark, K. B. (1994). Modularity-in-design: An analysis based on the theory of real options. Harvard Business School.

Baldwin, C. Y. and Clark, K.B. (1997), "Managing in an age of modularity", Harvard Business Review, Vol. 75 No. 5 , pp. 84-93.

Baldwin, C. Y. and Clark, K.B. (2000), Design Rules, MIT Press, Cambridge, Mass.

Baldwin, C. Y., MacCormack, A., \& Rusnak, J. (2014). Hidden structure: Using network methods to map system architecture. Research Policy, 43(8), 1381-1397.

Baldwin, C. And von Hippel, E. (2011), "Modeling a paradigm shift: From producer innovation to user and open collaborative innovation”, Organization Science, Vol. 22 No. 6, pp. 1399-1417.

Barney, J. (1991), "Firm resources and sustained competitive advantage", Journal of Management, Vol. 17 No. 1, pp. 99-120.

Bask, A., Lipponen, M., Rajahonka, M. and Tinnilä, M. (2010), "The concept of modularity: diffusion from manufacturing to service production”, Journal of Manufacturing Technology Management, Vol. 21 No. 3, pp. 355375.

Bask, A., Lipponen, M., Rajahonka, M., and Tinnilä, M. (2011). Framework for modularity and customization: service perspective. Journal of Business \& Industrial Marketing, 26(5), 306-319.

Bask, A., Merisalo-Rantanen, H. and Tuunanen, T. (2014), "Developing a Modular Service Architecture for E-store Supply Chains: The Small-and Medium-Sized Enterprise Perspective”, Service Science, Vol. 6 No. 4, pp. 251273.

Borgatti, S.P. (2002), Netdraw Network Visualization. Anylytic Technologies: Harvard, MA.

Borgatti, S.P., Everett, M.G. and Freeman, L.C. (2002), Ucinet 6 for Windows: Software for Social Network Analysis.

Borgman, C.L. and Furner, J. (2002). "Scholarly communication and bibliometrics", Annual review of information science. and technology, Vol. 36, pp. 2-72.

Browning, T.R. (2001), "Applying the design structure matrix to system decomposition and integration problems: a review and new directions", IEEE Transactions on Engineering Management, Vol. 48 No. 3, pp. 292-306.

Brusoni, S. (2005), "The limits to specialization: problem solving and coordination in "modular networks", Organization Studies, Vol. 26 No. 12, pp. 1885-1907.

Brusoni, S. and Prencipe, A. (2001), "Unpacking the black box of modularity: technologies, products and organizations", Industrial and Corporate Change, Vol. 10 No. 1, pp. 179-205.

Brusoni, S. and Prencipe, A. (2006), "Making design rules: A multidomain perspective", Organization science, Vol. 17 No. 2, pp. 179-189.

Brusoni, S., Prencipe, A. and Pavitt, K. (2001), "Knowledge specialization, organizational coupling, and the boundaries of the firm: why do firms know more than they make?", Administrative science quarterly, Vol. 46 No. 1, pp. 597 621

Buganza, T. and Verganti, R. (2006), "Life-cycle flexibility: How to measure and improve the innovative capability in 
turbulent environments",Journal of Product Innovation Management, Vol. 23 No. 5, pp. 393-407.

Cabigiosu, A., Campagnolo, D., Furlan, A., and Costa, G. (2015). "Modularity in KIBS: The case of third-party logistics service providers", Industry and Innovation, Vol. 22 No. 2, pp. 126-146.

Cabigiosu, A. and Camuffo, A. (2012), "Beyond the "mirroring" hypothesis: Product modularity and interorganizational relations in the air conditioning industry", Organization Science, Vol. 23 No. 3, pp. 686-703.

Cabigiosu, A., Zirpoli, F., and Camuffo, A. (2013), "Modularity, interfaces definition and the integration of external sources of innovation in the automotive industry", Research Policy, Vol. 42 No. 3, pp. 662-675.

Campagnolo, D. and Camuffo, A. (2010), "The Concept of Modularity in Management Studies: A Literature Review", International Journal of Management Reviews, Vol. 12 No. 3, pp. 259-283.

Caridi, M., Pero, M., and Sianesi, A. (2012), "Linking product modularity and innovativeness to supply chain management in the Italian furniture industry", International Journal of Production Economics, Vol. 136 No. 1, pp. 207-217.

Carlborg, P. and Kindström, D. (2014), "Service Process Modularization and Modular Strategies", Journal of Business \& Industrial Marketing, Vol. 29 No. 4, pp. 313-323.

Cebon, P., Hauptman, O., and Shekhar, C. (2008), "Product modularity and the product life cycle: new dynamics in the interactions of product and process technologies", International Journal of Technology Management, Vol. 42, No. 4, pp. 365-386.

Chandler, A. (1962), Strategy and Structure: Chapters in the History of the Industrial Enterprise, M.I.T. Press, Cambridge, Mass.

Chen, K. M. and Liu, R. J. (2005), "Interface strategies in modular product innovation", Technovation, Vol. 25 No. 7, pp. $771-782$.

Cheng, L. C. V., Cantor, D. E., Grimm, C. M.and Dresner, M. E. (2014), "Supply chain drivers of organizational flexibility—a study of US manufacturing industries", Journal of Supply Chain Management, Vol. 50 No. 4, pp. 62-75.

Chesbrough, H. (2003), "The logic of open innovation: managing intellectual property", California Management Review, Vol. 45 No. 3, pp. 33-58.

Christensen, C. and Rosenbloom, R. (1995),"Explaining the attackers advantage - technological paradigms, organizational dynamics and the value network", Research Policy, Vol. 24 No. 2, pp. 233-257.

Christensen, C. M. (1997), The Innovator's Dilemma: The Revolutionary Book that Will Change the Way You Do Business, Collins Business Essentials.

Christensen, C. M., Verlinden, M. and Westerman, G. (2002), "Disruption, disintegration and the dissipation of differentiability", Industrial and Corporate Change, Vol. 11 No. 5, pp. 955-993.

Clark, K. B. And Fujimoto, T. (1991), Product development performance: Strategy, organization, and management in the world auto industry, Harvard Business Press.

Clark, K.B. (1985), "The interaction of design hierarchies and market concepts in technological evolution", Research Policy, Vol. 14 No. 5, pp. 235-251.

Clark, K.B. and Wheelwright, S.C. (1993), Managing new product and process development, Free Press, New York.

Cohen, W. M. and Levinthal, D. A. (1990), "Absorptive-capacity - a new perspective on learning and innovation", Administrative Science Quarterly, Vol. 35 No. 1, pp. 12-152.

Collier, D.A. (1981), "The measurement and operating benefits of component part commonality", Decision Sciences, Vol. 12 No. 1, pp. 85-96.

Collier, D.A. (1982), "Aggregate safety stock levels and component part commonality", Management science, Vol. 28 No. 11, pp. 1296-1303.

Cusumano, M. A. (1991), Japan's software factories: a challenge to US management, Oxford University Press.

Danese, P., and Filippini, R. (2010), "Modularity and the Impact on New Product Development Time Performance Investigating the Moderating Effects of Supplier Involvement and Interfunctional Integration", International Journal of Operations \& Production Management, Vol. 30 No. 11, pp. 1191-1209.

Danese, P., and Filippini, R. (2013), "Direct and mediated effects of product modularity on development time and product performance", IEEE Transactions on engineering management, Vol. 60 No. 2, pp. 260-271.

De Blok, C., Luijkx, K., Meijboom, B. and Schols, J. (2010), "Modular care and service packages for independently living elderly", International Journal of Operations and Production Management, Vol. 30 No. 1, pp. 75-97. 
De Blok, C., Meijboom, B., Luijkx, K. and Schols, J. (2013), “The Human Dimension of Modular Care Provision: Opportunities for Personalization and Customization”, International Journal of Production Economics, Vol. 142, No. 1, pp. 16-26.

De Blok, C., Meijboom, B., Luijkx, K., Schols, J. And Schroeder, R. (2014), 'Interfaces in service modularity: A typology developed in modular health care provision", Journal of Operations Management, Vol. 32 No. 4, pp. 175-189.

Desai, P., Kekre, S., Radhakrishnan, S. and Srinivasan, K. (2001), "Product differentiation and commonality in design: Balancing revenue and cost drivers", Management Science, Vol. 47 No. 1, pp. 37-51.

Dierickx, I. and Cool, K. (1989), “Asset stock accumulation and sustainability of competitive advantage”, Management science, Vol. 35 No. 12, pp. 1504-1511.

Doran, D. and Hill, A. (2009), "A review of modular strategies and architecture within manufacturing operations", Proceedings of the Institution of Mechanical Engineers Part D-Journal of Automobile Engineering, 223(D1), pp. 65-75.

Droge, C., Vickery, S.K. and Jacobs, M.A. (2012), "Does supply chain integration mediate the relationships between product/process strategy and service performance? An empirical study”, International Journal of Production Eonomics, Vol. 137 No. 2, pp. 250-262

Duray, R., Ward, P. T., Milligan, G. W. and Berry, W. L. (2000), “Approaches to mass customization: configurations and empirical validation”, Journal of Operations Management, Vol. 18 No. 6, pp. 605-625.

Eisenhardt, K.M. (1989), "Building theories from case study research", Academy of management review, Vol. 14 No. 4 , pp. 532-550.

Eisenhardt, K.M. and Martin, J.A. (2000), “Dynamic capabilities: what are they?”, Strategic Management Journal, Vol. 21 No. 10-11, pp. 1105-1121.

Eissens-van der Laan, M., Broekhuis, M., van Offenbeek, M. and Ahaus, K. (2016). "Service Decomposition: A Conceptual Analysis of Modularizing Services." International Journal of Operations \& Production Management, Vol. 36, No. 3, pp. 308-331.

Eppinger, Steven D., Whitney, D. E., Smith, R. P. and Gebala, D. A. (1994), “A model-based method for organizing tasks in product development”, Research in Engineering Design, Vol. 6 No. 1, pp. 1-13.

Ernst, D. (2005), "Limits to modularity: reflections on recent developments in chip design", Industry and Innovation, Vol. 12 No. 3, pp. 303-335.

Ethiraj, S. K. and Levinthal, D. (2004b), "Modularity and innovation in complex systems”,Management Science, Vol. 50 No. 2, pp. 159-173.

Ethiraj, S. K., \& Levinthal, D. (2004a). Bounded rationality and the search for organizational architecture: An evolutionary perspective on the design of organizations and their evolvability. Administrative Science Quarterly, 49(3), 404-437.

Evans, D.H. (1963), "Modular design-A special case in nonlinear programming”, Operations Research, Vol. 11 No. 4 , pp. 637-647.

Feitzinger, E. and Lee, H. (1997), "Mass customization at Hewlett-Packard: the power of postponement", Harvard Business Review, Vol. 75 No. 1, pp. 116.

Fine, C. H. (1998), Clockspeed: Winning industry control in the age of temporary advantage, Basic Books.

Fine, C. H., Golany, B. and Naseraldin, H. (2005), "Modeling tradeoffs in three-dimensional concurrent engineering: a goal programming approach", Journal of Operations Management, Vol. 23 No. 3, pp. 389-403.

Fisher, M. (1997), "What is the right supply chain for your product?”, Harvard Business Review, Vol. 75 No. 2.

Fisher, M., Ramdas, K. and Ulrich, K. (1999), "Component sharing in the management of product variety: a study of automotive braking systems”, Management Science, Vol. 45 No. 3, pp. 297-315.

Fisher, M., Ramdas, K. and Ulrich, K. (1999), "Component sharing in the management of product variety: A study of automotive braking systems”, Management Science, Vol. 45 No. 3, pp. 297-315.

Fixson, S. K. (2005), "Product architecture assessment: a tool to link product, process, and supply chain design decisions", Journal of Operations Management, Vol. 23 No. 3-4, pp. 345-369.

Fixson, S. K. (2007), "Modularity and commonality research: past developments and future opportunities", Concurrent Engineering-Research and Applications, Vol. 15 No. 2, pp. 85-111.

Fixson, S. K. and Park, J. K. (2008), "The power of integrality: Linkages between product architecture, innovation, and industry structure”, Research Policy, Vol. 37 No. 8, pp. 1296-1316. 
Fleming, L. and Sorenson, O. (2001a), “Technology as a complex adaptive system: evidence from patent data”, Research Policy, Vol. 30 No. 7, pp. 1019-1039.

Fleming, L. and Sorenson, O. (2001b), “The dangers of modularity”, Harvard Business Review, Vol. 79 No. 8, pp. 2021.

Framinan, J. M. And Ruiz R. (2010), “Architecture of Manufacturing Scheduling Systems: Literature Review and an Integrated Proposal”, European Journal of Operational Research, Vol. 205 No. 2, pp. 237-246.

Galbraith, J. R. (1973), Designing complex organizations, Addison-Wesley Longman Publishing Co.

Galbraith, J.R. (1977), “Organization design: An information processing view, Organizational Effectiveness Center and School, Vol. 21, pp. 21-26.

Galunic, D.C. and Eisenhardt, K.M. (2001), "Architectural innovation and modular corporate forms", Academy of Management journal, Vol. 44 No. 6, pp. 1229-1249.

Garud, R. and Kumaraswamy, A. (1993), "Changing competitive dynamics in network industries - an exploration of Sun Microsystems open systems strategy”, Strategic Management Journal, Vol. 14 No. 5, pp. 351-369.

Garud, R. and Kumaraswamy, A. (1995), "Technological and organizational designs for realizing economies of substitution", Strategic Management Journal, Vol. 16, pp. 93-109.

Garud, R., Kumaraswamy, A. and Langlois, R. (Eds.). (2009). Managing in the modular age: architectures, networks, and organizations. John Wiley \& Sons.

Gatignon, H., Tushman, M. L., Smith, W. and Anderson, P. (2002), “A structural approach to assessing innovation: construct development of innovation locus, type, and characteristics”, Management Science, Vol. 48 No. 9, pp. 1103-1122.

Gavetti, G. and Levinthal, D. (2000), "Looking forward and looking backward: Cognitive and experiential search", Administrative science quarterly, Vol. 45 No. 1, pp. 113-137.

Gavetti, G., Levinthal, D. A. and Rivkin, J. W. (2005), "Strategy making in novel and complex worlds: the power of analogy", Strategic Management Journal, Vol. 26 No. 8, pp. 691-712.

Gawer, A. and Cusumano, M. A. (2002), Platform leadership: How Intel, Microsoft, and Cisco drive industry innovation, Harvard Business School Press, Boston.

Gerchak, Y., Magazine, M. J. and Gamble, A. B. (1988), “Component commonality with service level requirements”, Management science, Vol. 34 No. 6, pp. 753-760.

Gershenson, J. K., Prasad, G. J. and Zhang, Y. (2003), "Product modularity: definitions and benefits", Journal of Engineering design, Vol. 14 No. 3, pp. 295-313.

Glaser, B. and Strauss, A. (1967), The discovery of grounded theory, Weidenfeld and Nicholson, London.

Gunasekaran, A. and Ngai, E. W. T. (2005), "Build-to-order supply chain management: a literature review and framework for development”, Journal of Operations Management, Vol. 23 No. 5, pp. 423-451.

Gupta, S. and Krishnan, V. (1999), "Integrated component and supplier selection for a product family", Production and Operations Management, Vol. 8 No. 2, pp. 163.

Helfat, C. E. (2015), "Vertical firm structure and industry evolution", Industrial and Corporate Change, Vol. 24 No. 4 , pp. 803-818.

Helfat, C.E. and Eisenhardt, K. M. (2004), "Inter-temporal economies of scope, organizational modularity, and the dyanamics of diversification”, Strategic Management Journal, Vol. 25 No. 13, pp. 1217-1232.

Hellström, M. (2014), "Solution business models based on functional modularity-the case of complex capital goods", Journal of Service Management, Vol. 25 No. 5, pp. 654-676.

Henderson, R. M. and Clark, Kim B. (1990), "Architectural innovation - the reconfiguration of existing product technologies and the failure of established firms", Administrative Science Quarterly, Vol. 35 No. 1, pp. 9-30.

Hobday, M., Davies, A. and Prencipe, A. (2005), "Systems integration: a core capability of the modern corporation", Industrial and corporate change, Vol. 14 No. 6, pp. 1109-1143.

Hoetker, G. (2006), “Do modular products lead to modular organizations?”, Strategic Management Journal, Vol. 27 No. 6, pp 501-518.

Hoetker, G., Swaminathan, A. and Mitchell, W. (2007), "Modularity and the impact of buyer-supplier relationships on the survival of suppliers", Management Science, Vol. 53 No. 2, pp. 178-191.

Hofman, E. And Meijerink, J. (2015), "Platform thinking for services: the case of human resources", The Service Industries Journal, Vol. 35 No. 3, pp. 115-132. 
Hong, Y. And Hartley, J. L. (2011), "Managing the supplier-supplier interface in product development: The moderating role of technological newness", Journal of Supply Chain Management, Vol. 47 No. 3, pp. 43-62.

Howard, M. and Squire, B. (2007), "Modularization and the impact on supply relationships", International Journal of Operations and Production Management, Vol. 27 No. 11, pp. 1192-1212.

Hsuan, J. (1999)", Impacts of supplier-buyer relationships on modularization in new product development", European Journal of Purchasing \& Supply Management, Vol. 5 No. 3, pp. 197-209.

Hsuan, J. And Mahnke, V. (2011), “Outsourcing R\&D: A Review, Model, and Research Agenda”, R\&D Management, Vol. 41 No. 1, pp. 1-7.

Huang, G. Q., Zhang, X. Y. and Liang, L. (2005), “Towards integrated optimal configuration of platform products, manufacturing processes, and supply chains", Journal of Operations Management, Vol. 23 No. 3, pp. 267-290.

Huang, G. Q., Zhang, X. Y. And Lo, V. H. (2007), 'Integrated configuration of platform products and supply chains for mass customization: a game-theoretic approach, IEEE Transactions on Engineering Management, Vol. 54 No. 1, pp. 156-171.

Jacobides, M. G. (2005), "Industry change through vertical disintegration: How and why markets emerged in mortgage banking”, Academy of Management Journal, Vol. 48 No. 3, pp. 465-498.

Jacobides, M. G., and Billinger, S. (2006), "Designing the boundaries of the firm: From "make, buy, or ally" to the dynamic benefits of vertical architecture", Organization science, Vol. 17 No. 2, pp. 249-261.

Jacobides, M. G. and Winter, S. G. (2005), "The co-evolution of capabilities and transaction costs: Explaining the institutional structure of production”, Strategic Management Journal, Vol. 26 No. 5, pp. 395-413.

Jacobs, M., Droge, C., Vickery, S. K. and Calantone, R. (2011), "Product and process modularity's effects on manufacturing agility and firm growth performance", Journal of Product Innovation Management, Vol. 28 No. 1, pp. $123-137$.

Jacobs, M., Vickery, S. K. and Droge, C. (2007), "The effects of product modularity on competitive performance: do integration strategies mediate the relationship?”, International Journal of Operations \& Production Management, Vol. 27 No. 10, pp. 1046-1068.

Jaspers, F. And Van den Ende, J. (2010), "Open innovation and systems integration: how and why firms know more than they make", International Journal of Technology Management, Vol. 52 No. 3/4, pp. 275-294.

Jiao, J. and Tseng, M. M. (1999), "A methodology of developing product family architecture for mass customization”, Journal of Intelligent Manufacturing, Vol. 10 No. 1, pp. 3-20.

Kapoor, R. (2013), "Persistence of integration in the face of specialization: How firms navigated the winds of disintegration and shaped the architecture of the semiconductor industry", Organization Science, Vol. 24, No. 4, pp. 1195-1213.

Karim, S. (2006), "Modularity in organizational structure: the reconfiguration of internally developed and acquired business units", Strategic Management Journal, Vol. 27 No. 9, pp. 799-823.

Kauffman, S. (1993), The Origins of Order: Self-organization and Selection in Evolution, Oxford University Press.

Kim, K. and Chhajed, D. (2000), "Commonality in product design: Cost saving, valuation change and cannibalization", European Journal of Operational Research, Vol. 125 No. 3, pp. 602-621.

Kogut, B. and Zander, U. (1992), "Knowledge of the firm, combinative capabilities, and the replication of technology", Organization science, Vol. 3 No. 3, pp. 383-397.

Kong, F. B., Ming, X. G., Wang, L., Wang, X. H. and Wang, P. P. (2009), “On modular products development”, Concurrent Engineering-Research and Applications, Vol. 17 No. 4, pp. 291-300.

Kotha, S. (1995), "Mass customization: implementing the emerging paradigm for competitive advantage", Strategic Management Journal, Vol. 16 No. S1, pp. 21-42.

Krishnan, V. and Gupta, S. (2001), “Appropriateness and impact of platform-based product development”, Management Science, Vol. 47 No. 1, pp. 52-68.

Kusiak, A. and Huang, C. C. (1996), "Development of modular products", IEEE Transactions on Components, Packaging, and Manufacturing Technology, Part A, Vol. 19 No. 4, pp. 523-538.

Langlois, R. N. (2002), "Modularity in technology and organization", Journal of Economic Behavior and Organization, Vol. 49 No. 1, pp. 19-37.

Langlois, R. N. and Robertson, P. L. (1992), "Networks and innovations in a modular system - lessons from the microcomputer and stereo component industries", Research Policy, Vol. 21 No. 4, pp. 297-313. 
Langlois, R.N. (2003), “The vanishing hand: the changing dynamics of industrial capitalism", Industrial and corporate change, Vol. 12 No. 2, pp. 351-385.

Lau, A. K. W., Yam, R. C. M. and Tang, E. P. Y. (2010), "Supply chain integration and product modularity:an empirical study of product performance for selected Hong Kong manufacturing industries", International Journal of Operations and Production Management, Vol. 30 No. 1, pp. 20-56.

Lau, A. K., Yam, R., and Tang, E. (2011), "The impact of product modularity on new product performance: Mediation by product innovativeness.” Journal of Product Innovation Management, Vol. 28 No. 2, pp. 270-284.

Lau, A. K. (2011), "Critical success factors in managing modular production design: Six company case studies in Hong Kong, China, and Singapore”, Journal of Engineering and Technology Management, Vol. 28 No. 3, pp. 168-183.

Lawrence, P. R. and Lorsch, J. W. (1967), Managing differentiation and integration. Organization and environment.

Lei, D. (2003), "Competition, cooperation and learning: the new dynamics of strategy and organisation design for the innovation net”, International Journal of Technology Management, Vol. 26 No. 7, pp. 694-716.

Lei, D. (2000), "Industry evolution and competence development: the imperatives of technological convergence" International Journal of Technology Management, Vol. 19, No. 7-8, pp. 699-738.

Lei, D., Hitt, M. A., and Goldhar, J. D. (1996), “Advanced manufacturing technology: Organizational design and strategic flexibility”, Organization Studies, Vol. 17 No. 3, pp. 501-523.

Leonard-Barton, D. (1992), "Core capabilities and core rigidities - a paradox in managing new product development", Strategic Management Journal, Vol. 13, pp. 111-125.

Levinthal, D. A. (1997), “Adaptation on rugged landscapes”, Management Science, Vol. 43 No. 7, pp. 934-950.

Lin, Y., and Pekkarinen, S. (2011), “QFD-Based Modular Logistics Service Design”, Journal of Business \& Industrial Marketing, Vol. 26 No. 5, pp. 344-356.

MacCormack, A., Verganti, R. and Iansiti, M. (2001),“Developing products on 'Internet time': the anatomy of a flexible development process”,Management Science, Vol. 47 No. 1, pp. 133-150.

MacDuffie, J. P. (2013), "Modularity-as-property, modularization-as-process, and 'modularity'-as-frame: Lessons from product architecture initiatives in the global automotive industry", Global Strategy Journal, Vol. 3 No. 1, pp. 840.

Malone, T.W., Yates, J. and Benjamin, R.I. (1987), "Electronic markets and electronic hierarchies", Communications of the ACM, Vol. 30 No. 6, pp. 484-497.

March, J. G. (1991), "Exploration and exploitation in organizational learning”, Organization Science, Vol. 2 No. 1, pp. $71-87$.

March, J. G. and Simon, H. A. (1958). Organizations.

Martin, J. A., and Eisenhardt, K. M. (2004), "Coping with decline in dynamic markets: Corporate entrepreneurship and the recombinative organizational form”, In J. A. C. Baum and A. M. McGahan (Eds.), Business Strategy over the Industry Life Cycle (Advances in strategic management, Volume 21. pp. 357-382. Bingley: Emerald Group Publishing Limited.

Meyer, M. H. and Lehnerd, A. P. (1997), The Power of Product Platforms: Building Value and Cost Leadership, Free Press.

Meyer, M. H., Tertzakian, P. and Utterback, J. M. (1997), "Metrics for managing research and development in the context of the product family", Management Science, Vol. 43 No. 1, pp. 88-111.

Mikkola, J. H. (2006), "Capturing the degree of modularity embedded in product architectures", Journal of Product Innovation Management, Vol. 23 No. 2, pp. 128-146.

Mikkola, J. H. and Gassmann, O. (2003), "Managing modularity of product architectures: toward an integrated theory", IEEE Transactions on Engineering Management, Vol. 50 No. 2, p. 204.

Mikkola, J. H. and Skjøtt-Larsen, T. (2004), "Supply-chain integration: implications for mass customization, modularization and postponement strategies", Production Planning and Control, Vol. 15 No. 4, pp. 352-361.

Mikkola, J.H. (2003), "Modularity, component outsourcing, and inter-firm learning", $R$ and D Management, Vol. 33 No. 4, pp. 439-454.

Miles, M. B. and Huberman, A. M. (1984). Qualitative data analysis: A sourcebook of new methods.

Monteverde, K. (1995), "Technical dialog as an incentive for vertical integration in the semiconductor industry", Management Science, Vol. 41 No. 10, pp. 1624-1638. 
Morris, C. R. and Ferguson, C. H. (1993), "How architecture wins technology wars", Harvard Business Review, Vol. 71 No. 2, pp. 86-96.

Murmann, J. P. and Frenken, K. (2006), “Toward a systematic framework for research on dominant designs, technological innovations, and industrial change”, Research Policy, Vol. 35 No. 7, pp. 925-952.

Nelson, R. and Winter, S. G. (1982), An Evolutionary Theory of Economic Change, Belknap Press of Harvard University Press.

Newman, M. (2010) Networks: An Introduction. Oxford University Press.

Normann, R. and Ramirez, R. (1993), "From value chain to value constellation", Harvard business review, Vol. 71 No. 4, pp. 65-77.

Novak, S. and Eppinger, S. D. (2001), "Sourcing by design: Product complexity and the supply chain", Management science, Vol. 47 No. 1, pp. 189-204.

Orton, J. D. and Weick, K. E. (1990), "Loosely coupled systems: A reconceptualization”, Academy of management review, Vol. 15 No. 2, pp. 203-223.

Pahl, G., Beitz, W. and Wallace, K. (1996), Engineering design,

Park, J. K., and Ro, Y. K. (2011), “The impact of a firm's make, pseudo-make, or buy strategy on product performance”, Journal of Operations Management, Vol. 29 No. 4, pp. 289-304.

Parmigiani, A., and Mitchell, W. (2009), "Complementarity, capabilities, and the boundaries of the firm: the impact of within-firm and interfirm expertise on concurrent sourcing of complementary components", Strategic Management Journal, Vol. 30 No. 10, pp. 1065-1091.

Parnas D. L. (1972), “On the Criteria to Be Used in Decomposing Systems into Modules", Communications of the Acm, Vol. 15 No. 12, pp. 1053-1058.

Parslov, J. F. And Mortensen, N. H. (2015), "Interface Definitions in Literature: A Reality Check", Concurrent Engineering, Vol. 23 No. 3, pp. 183-198.

Pashaei, S. And Olhager.J. (2015), "Product Architecture and Supply Chain Design: A Systematic Review and Research Agenda", Supply Chain Management: An International Journal, January.

Pekkarinen, S. and Ulkuniemi, P. (2008), "Modularity in developing business services by platform approach", The International Journal of Logistics Management, Vol. 19 No. 1, pp. 84-103.

Peng, X. D., Liu, G., and Heim, G. R. (2011), "Impacts of information technology on mass customization capability of manufacturing plants”, International Journal of Operations \& Production Management, Vol. 31 No. 10, pp. 10221047.

Penrose, E. (1959), The Theory of the Growth in the Firm, Blackwell.

Pero, M., Abdelkafi, N., Sianesi, A. and Blecker, T. (2010), “A framework for the alignment of new product development and supply chains", Supply Chain Management-An International Journal, Vol. 15 No. 2, pp. 115-128.

Pil, F. K. and Cohen, S. K. (2006), "Modularity: Implications for imitation, innovation, and sustained advantage", Academy of Management Review, Vol. 31 No. 4, pp. 995-1011.

Pilkington, A. And Chai, K. H. (2008), "Research Themes, Concepts and Relationships: A Study of International Journal of Service Industry Management (1990-2005)”, International Journal of Service Industry Management, Vol. 19 No. 1, pp. 83-110.

Pilkington, A. and Fitzgerald, R. (2006), “Operations management themes, concepts and relationships: a forward retrospective of IJOPM", International Journal of Operations and Production Management, Vol. 26 No. 11-12, pp. 1255-1275.

Pilkington, A., Raja, J. Z., Hsuan, J., Frandsen, T. (2015), “Locating Servitization Within the Wider Communities : A Bibliometric Approach", in proceedings of the $22^{\text {nd }}$ International Product Development Management Conference, Copenhagen, Denmark.

Pilkington, A. and Meredith, J. (2009), "The evolution of the intellectual structure of operations management-1980-2006: a citation/co-citation analysis", Journal of Operations Management, Vol. 27 No. 3, pp. 185-202.

Pine, B. (1993) Mass Customization: The New Frontier in Business Competition.Harvard Business School Press.

Podsakoff, P. M., MacKenzie, S. B., Lee, J. Y. and Podsakoff, N. P. (2003), "Common method biases in behavioral research: a critical review of the literature and recommended remedies", Journal of applied psychology, Vol. 88 No. 5, pp. 879.

Porter, M. E. (1985), Competitive advantage: creating and sustaining superior performance, 
Porter, M. E. (1996), “What Is Strategy?”, Harvard Business Review, Vol. 74 No. 6, pp. 61-78.

Prahalad, C. K. and Hamel, G. (1990), “The Core Competence of the Corporation”, Harvard Business Review, Vol. 68 No. 3, pp. 79-91.

Ragatz, G. L., Handfield, R. B. and Scannell, T. V. (1997), "Success factors for integrating suppliers into new product development", Journal of product innovation management, Vol. 14 No. 3, pp. 190-202.

Rajahonka, M. (2013), "Views of Logistics Service Providers on Modularity in Logistics Services”, International Journal of Logistics-Research and Applications, Vol. 16 No. 1, pp. 34-50.

Reichhart, A. And Holweg, M. (2013), "Creating the Customer-responsive Supply Chain: A Reconciliation of Concepts", International Journal of Operations \& Production Management, Vol. 27 No. 11, pp.1144 - 1172.

Rivkin, J. (2000), “Imitation of complex strategies”, Management Science, Vol. 46 No. 6, pp. 824-844.

Rivkin, J. W. and Siggelkow, N. (2003), "Balancing search and stability: Interdependencies among elements of organizational design", Management Science, Vol. 49 No. 3, pp. 290-311.

Ro, Y. K., Liker, J. K. and Fixson, S. K. (2007), "Modularity as a strategy for supply chain coordination: the case of US auto", IEEE Transactions on Engineering Management, Vol. 54 No. 1, pp. 172-189.

Robertson, D. and Ulrich, K. (1998), "Platform product development”, Sloan management review, Vol. 39 No. 4, pp. 1931.

Rutenberg, D. P. (1971), "Design commonality to reduce multi-item inventory: Optimal depth of a product line", Operations Research, Vol. 19 No. 2, pp. 491-509.

Sako, M. (2003), "Modularity and outsourcing: The nature of co-evolution of product architecture and organisation architecture in the global automotive industry", in Prencipe, A., Davies, A. and Hobday, M. (eds.), The business of systems integration, Oxford University Press, Oxford, pp. 229-253.

Salvador, F. (2007), "Toward a product system modularity construct: literature review and reconceptualization", IEEE Transactions on Engineering Management, Vol. 54 No. 2, pp. 219-240.

Salvador, F., Forza, C. and Rungtusanatham, M. (2002), "Modularity, product variety, production volume, and component sourcing: theorizing beyond generic prescriptions", Journal of Operations Management, Vol. 20 No. 5, pp. 549-575.

Salvador, F., Rungtusanatham, M. and Forza, C. (2004), "Supply-chain configurations for mass customization", Production Planning and Control, Vol. 15 No. 4, pp. 381-397.

Salvador, F., and Villena, V. H. (2013), "Supplier integration and NPD outcomes: Conditional moderation effects of modular design competence", Journal of Supply Chain Management, Vol. 49, No. 1, pp. 87-113.

Sanchez, R. (1995), "Strategic flexibility in product competition", Strategic Management Journal, Vol. 16, pp. $135-159$.

Sanchez, R. (1996), "Strategic product creation: Managing new interactions of technology, markets, and organizations", European Management Journal, Vol. 14 No. 2, pp. 121-138.

Sanchez, R. (1999), "Modular architectures in the marketing process", Journal of Marketing, Vol. 63, pp. 92-111.

Sanchez, R. (2000), "Modular architectures, knowledge assets and organisational learning: new management processes for product creation", International Journal of Technology Management, Vol. 19 No. 6, pp. 610-629.

Sanchez, R. and Mahoney, J. T. (1996), "Modularity, flexibility, and knowledge management in product and organization design”, Strategic Management Journal, Vol. 17, pp. 63-76.

Sanchez, R., \& Sudharshan, D. (1993), "Real-time market research", Marketing intelligence \& planning, Vol. 11 no. 7, pp. 29-38.

Sanderson, S. W. and Uzumeri, M. (1997), Managing product families. Irwin Professional Pub.

Sanderson, S. W. and Uzumeri, V. (1990), Strategies for new product development and renewal: design-based incrementalism, Center Sci. Technol. Policy, Rensselaer Polytechnic Inst., Troy, NY.

Schilling, M. A. (2000), "Toward a general modular systems theory and its application to interfirm product modularity", Academy of Management Review, Vol. 25 No. 2, pp. 312-334.

Schilling, M. A. and Steensma, H. K. (2001), "The use of modular organizational forms: an industry-level analysis", Academy of Management Journal, Vol. 44 No. 6, pp. 1149-1168.

Siggelkow, N. and Levinthal, D. A. (2003), “Temporarily divide to conquer: centralized, decentralized, and reintegrated organizational approaches to exploration and adaptation", Organization Science, Vol. 14 No. 6, pp. 650-669.

Siggelkow, N. and Rivkin, J. W. (2005), "Speed and search: designing organizations for turbulence and complexity", Organization Science, Vol. 16 No. 2, pp. 101-122. 
Simon, H.A. (1962), “The architecture of complexity”, Proceedings of the American Philosophical Society, Vol. 102 No. 6, pp. 467-482.

Sinha, K. K., and Van de Ven, A. H. (2005), "Designing Work Within and Between Organizations." Organization Science, Vol. 16 No. 4, pp. 389-408.

Sosa, M. E., Eppinger, S.D. and Rowles, C. M. (2004), "The misalignment of product architecture and organizational structure in complex product development", Management Science, Vol. 50 No. 12, pp. 1674-1689.

Starr, M. K. (1965),“Modular production - anew concept”, Harvard Business Review, Vol. No. 6, pp. 131.

Starr, M. K. (2010), "Modular Production - a 45-Year-Old Concept”, International Journal of Operations \& Production Management, Vol. 30, No. 1, pp. 7-19.

Staudenmayer, N., Tripsas, M. and Tucci, C. L. (2005), "Interfirm modularity and its implications for product development", Journal of Product Innovation Management, Vol. 22 No. 4, pp. 303-321.

Steward, D. V. (1981), "The design structure system: A method for managing the design of complex systems", IEEE Transactions on Engineering Management, Vol. EM-28, No.3, pp. 71-74.

Strauss, A. and Corbin, J. (1998), Basics of qualitative research: Procedures and techniques for developing grounded theory,

Sturgeon, T. J. (2002), "Modular production networks: a new American model of industrial organization", Industrial and corporate change, Vol. 11 No. 3, pp. 451-496.

Suh, N. P. (1990). The principles of design (Vol. 990). New York: Oxford University Press.

Takeishi, A. (2002), "Knowledge partitioning in the interfirmdivision of labor: the case of automotive product development", Organization Science, Vol. 13 No. 3, pp. 321-338.

Teece, D. J., Pisano, G. and Shuen, A. (1997), "Dynamic capabilities and strategic management”, Strategic Management Journal, Vol. 18 No. 7, pp. 509-533.

Teece, D.J. (1986), "Profiting from technological innovation - implications for integration, collaboration, licensing and public-policy", Research Policy, Vol. 15 No. 6, pp. 285-305.

Terjesen, S., Patel, P. C., and Sanders, N. R. (2012), "Managing Differentiation-Integration Duality in Supply Chain Integration", Decision Sciences, Vol. 43, No. 2, pp. 303-339.

Thompson, J. (1967), Organizations in Action: Social Science Bases of Administrative Theory, McGraw-Hill.

Tiwana, A. (2008a), "Does interfirmmodularity complement ignorance? Afield study of software outsourcing alliances, Strategic Management Journal, Vol. 29 No. 11, pp. 1241-1252.

Tu, Q., Vonderembse, M. A., Ragu-Nathan, T. S. and Ragu-Nathan, B. (2004), "Measuring modularity-based manufacturing practices and their impact on mass customization capability: acustomer-driven perspective", Decision Sciences, Vol. 35 No. 2, pp. 147-168.

Tushman, M. L. and Anderson, P. (1986), "Technological discontinuities and organizational environments", Administrative Science Quarterly, Vol. 31 No. 3, pp. 439-465.

Tushman, M. L. and Nadler, D. A. (1978), "Information Processing as an Integrating Concept in Organizational Design", Academy of management review, Vol. 3 No. 3, pp. 613-624.

Ülkü, S., and Schmidt, G. M. (2011), "Matching product architecture and supply chain configuration", Production and Operations Management, Vol. 20 No. 1, pp. 16-31.

Ulrich, K. (1995), "The role of product architecture in the manufacturing firm", Research Policy, Vol.24 No. 3, pp. 419-440.

Ulrich, K. and Eppinger S. D. (1995), Product Design and Development. New York: McGraw-Hill Education.

Ulrich, K. T. and Tung, K. (1991), Fundamentals of Product Modularity Issues in Design/Manufacture Integration, 73 79. Sharon, Ed. New York: ASME.

Utterback, J. (1994). Mastering the dynamics of innovation: how companies can seize opportunities in the face of technological change. University of Illinois at Urbana-Champaign's Academy for Entrepreneurial Leadership Historical Research Reference in Entrepreneurship.

Vähätalo, M. And Kallio, T. J. (2015), "Organising health services through modularity", International Journal of Operations \& Production Management, Vol. 35 no. 6, pp. 925-945.

Van Hoek, R. I. and Weken, H. A. (1998), "The impact of modular production on the dynamics of supply chains", The International Journal of Logistics Management, Vol. 9 No. 2, pp. 35-50. 
Venkatesan, R. (1992), “Strategic Sourcing: To make or not to make, Harvard Business Review, Vol. 70 No. 6, pp. 98 107.

Verganti, R. and Buganza, T. (2005), "Designing for life-cycle flexibility in Internet-based service", Journal of Product Innovation Management, Vol. 22 No. 3, pp. 223-237.

Vickery, S. K., Bolumole, Y. A., Castel, M. J. And Calantone, R. J. (2015), “The effects of product modularity on launch speed”, International Journal of Production Research, Vol. 53 No. 17, pp. 5369-5381.

Vogel, R., and Güttel, W. H. (2013). "The Dynamic Capability View in Strategic Management: A Bibliometric Review." International Journal of Management Reviews, Vol. 15 No. 4, pp. 426-446.

Von Hippel, E. (1994), “"'Sticky information” and the locus of problem solving: implications for innovation", Management science, Vol. 40 No. 4, pp. 429-439.

Von Hippel, E., (1990), “Task Partitioning - An Innovation Process Variable”, Research Policy, Vol. 19 No. 5, pp. 407418.

Voordijk, H., Meijboom, B. and de Haan, J. (2006), "Modularity in supply chains: a multiple case study in the construction industry", International Journal of Operations \& Production Management, Vol. 26 No. 6, pp. 600-618.

Voss, C. A. and Hsuan, J. (2009), "Service architecture and modularity”, Decision Sciences, Vol. 40 No. 3, pp. $541-569$.

Voss, C., Tsikriktsis, N. and Frohlich, M. (2002), "Case research in operations management”, International journal of operations \& production management, Vol. 22 No. 2, pp. 195-219.

Weick, K. (1979), The social psychology of organisations. Reading: Addison Wesley.

Weick, K. E., (1976), "Educational Organizations as Loosely Coupled Systems”, Administrative Science Quarterly, Vol. 21 No. 1, pp. 1-19.

Wheelwright, S. C. and Clark, K. B. (1992), Revolutionizing product development: quantum leaps in speed, efficiency, and quality, Simon and Schuster.

Williamson, O.E. (1985), The Economic Institutions of Capitalism Firms, Markets, Relational Contracting, Free Press.

Worren, N., Moore, K. and Cardona, P. (2002), "Modularity, strategic flexibility, and firm performance: a study of the home appliance industry", Strategic Management Journal, Vol. 23 No. 12, pp. 1123-1140.

Yassine, A. A. and Wissmann, L. A. (2007), “The implications of product architecture on the firm”, Systems Engineering, Vol. 10 No. 2, pp. 118-137.

Yayavaram, S. And Ahuja, G. (2008), "Decomposability in knowledge structures and its impact on the usefulness of inventions and knowledge-base malleability", Administrative Science Quarterly, Vol. 53 No. 2, pp. 333-362.

Yin, R. (1994), Case study research: Design and methods, Beverly Hills.

Zhang, L. L. (2015), “A Literature Review on MultitypePlatforming and Framework for Future Research", International Journal of Production Economics, Vol. 168 (October), pp. 1-12.

Zhang, X., and Huang, G. Q. (2010), "Game-theoretic approach to simultaneous configuration of platform products and supply chains with one manufacturing firm and multiple cooperative suppliers", International Journal of Production Economics, Vol. 124 No. 1, pp. 121-136.

Zhang, X., Huang, G. Q. and Rungtusanatham, M. J. (2008), "Simultaneous configuration of platform products and manufacturing supply chains", International Journal of Production Research, Vol. 46 No. 21, pp. 6137-6162.

Zhou, Y. M. (2013), "Designing for complexity: Using divisions and hierarchy to manage complex tasks", Organization Science, Vol. 24 No. 2, pp. 339-355.

Zirpoli, F., and Becker, M. C. (2011), "The limits of design and engineering outsourcing: performance integration and the unfulfilled promises of modularity”, $R \& D$ Management, Vol. 41 No. 1, pp. 21-43. 
INSERT APPENDIX I ABOUT HERE

INSERT APPENDIX II ABOUT HERE

INSERT APPENDIX III ABOUT HERE 
Figure 1. Analytical approach to identifying the structure within the modularity literature

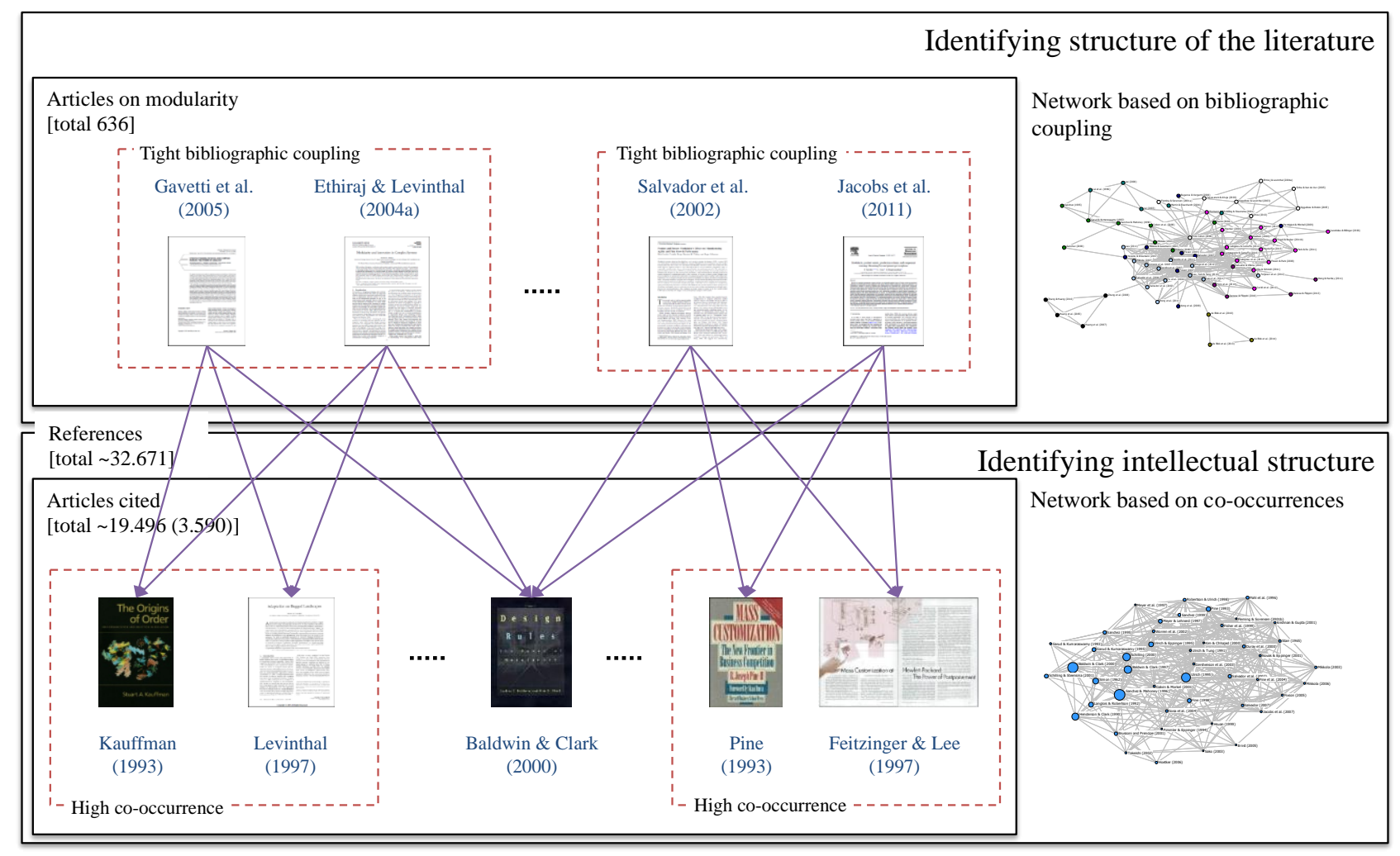

Source: Bibliographic data from the literature search on modularity 
Figure 2. Example of referencing from a subset of the modularity literature

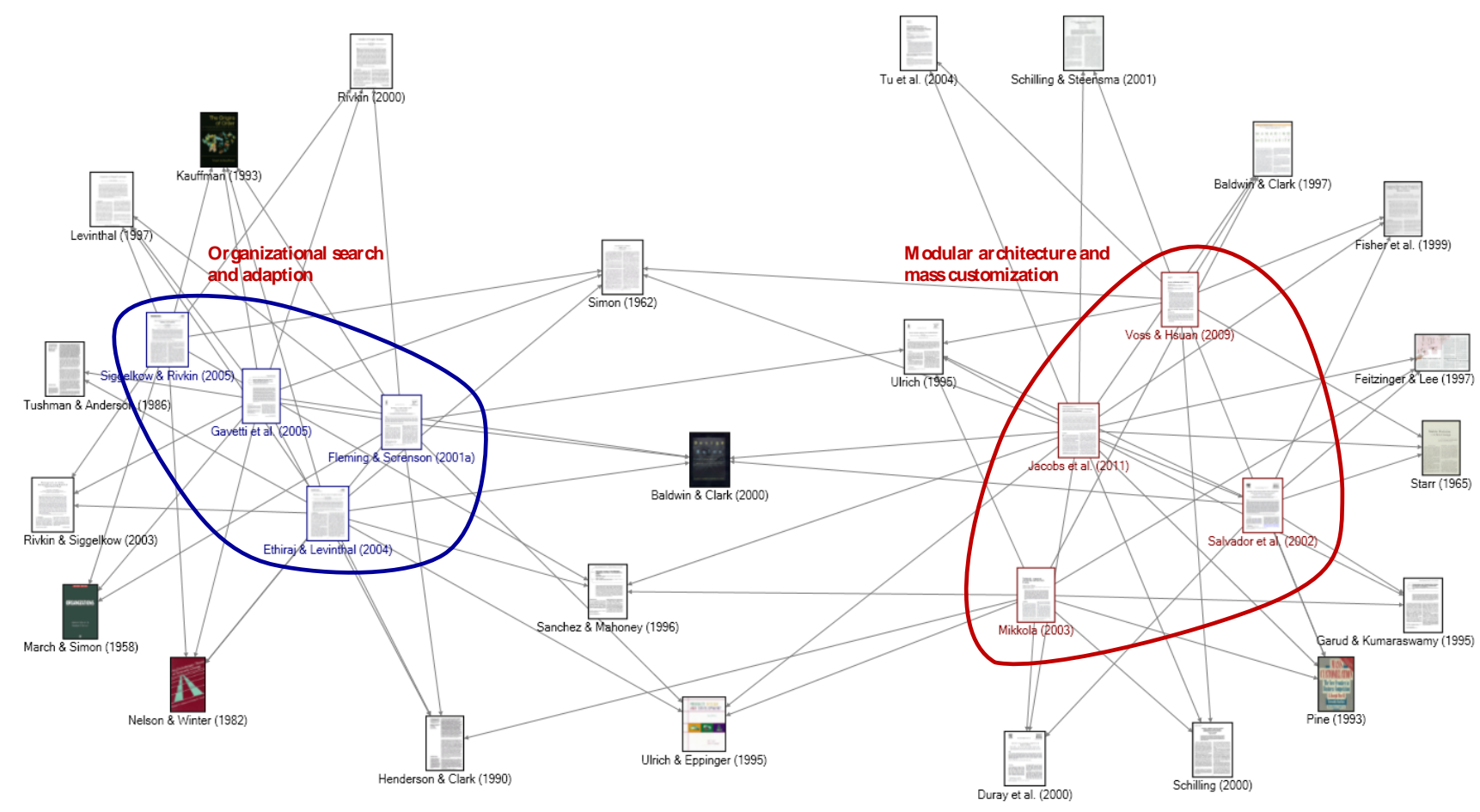

Source: Bibliographic data from the literature search on modularity 
Table I. Key principles on which the modularity literature draws

\begin{tabular}{|c|c|c|c|}
\hline Author & Research area & Key principle & Implication \\
\hline $\begin{array}{l}\text { Simon } \\
(1962)\end{array}$ & $\begin{array}{l}\text { General systems } \\
\text { theory }\end{array}$ & $\begin{array}{l}\text { Near decomposable } \\
\text { systems }\end{array}$ & $\begin{array}{l}\text { Decomposing systems hierarchically is the primary method by } \\
\text { which designers can reduce complexity }\end{array}$ \\
\hline $\begin{array}{l}\text { Alexander } \\
(1964)\end{array}$ & Design & $\begin{array}{l}\text { Decomposition of } \\
\text { systems }\end{array}$ & $\begin{array}{l}\text { Suggests a program of functional decomposition, based on } \\
\text { identifying the requirement variables and their } \\
\text { interdependencies, as the key to solving design problems }\end{array}$ \\
\hline $\begin{array}{l}\text { Starr } \\
(1965)\end{array}$ & $\begin{array}{l}\text { Operations } \\
\text { Management }\end{array}$ & Modular production & $\begin{array}{l}\text { Proposes modular production as a method for increasing } \\
\text { flexibility in manufacturing systems }\end{array}$ \\
\hline $\begin{array}{l}\text { Thompson } \\
\text { (1967) }\end{array}$ & $\begin{array}{l}\text { Organizational } \\
\text { studies }\end{array}$ & $\begin{array}{l}\text { Interdependencies of } \\
\text { components }\end{array}$ & $\begin{array}{l}\text { Complex organizations are natural systems subject to } \\
\text { rationality norms, which, at the same time, attempt to adapt to } \\
\text { environment change and reduce uncertainty }\end{array}$ \\
\hline $\begin{array}{l}\text { Parnas } \\
(1972)\end{array}$ & $\begin{array}{l}\text { Information } \\
\text { systems }\end{array}$ & Information hiding & $\begin{array}{l}\text { Modules should be characterized by the knowledge of key } \\
\text { design decisions, and this should be hidden from others }\end{array}$ \\
\hline $\begin{array}{l}\text { Weick } \\
(1976)\end{array}$ & $\begin{array}{l}\text { Organizational } \\
\text { studies }\end{array}$ & Loose Coupling & $\begin{array}{l}\text { Suggests a dialectic interpretation of loose coupling as systems } \\
\text { in which responsiveness and distinctiveness are simultaneously } \\
\text { present }\end{array}$ \\
\hline $\begin{array}{l}\text { Von } \\
\text { Hippel } \\
(1990)\end{array}$ & $\begin{array}{l}\text { Innovation } \\
\text { process research }\end{array}$ & Task partitioning & $\begin{array}{l}\text { Suggests that the way tasks are partitioned in innovation } \\
\text { projects has important effects on innovation efficiency and } \\
\text { effectiveness }\end{array}$ \\
\hline
\end{tabular}


Table II. Source articles by search criteria

In title, abstract or $\mathrm{KW}$

Modularity

Modular AND architecture

Modular AND design

Multiple of criteria 1-3

Included in search
Only in KW+

Total

161

49

210

40

207

1

41

240

321

33

76

397

729 
Table III. Journals most frequently cited by papers on modularity

\begin{tabular}{|c|c|c|c|c|c|c|c|c|c|c|c|}
\hline $\begin{array}{l}\text { Early period: 1990-1999 } \\
\text { Journal }\end{array}$ & & $\begin{array}{r}\% \\
\text { citations } \\
\end{array}$ & $\begin{array}{l}\text { Middle period: 2000-2009 } \\
\text { Journal }\end{array}$ & & $\begin{array}{r}\% \\
\text { citations } \\
\end{array}$ & $\begin{array}{l}\text { Recent period: 2010-2015 } \\
\text { Journal } \\
\end{array}$ & & $\begin{array}{r}\% \\
\text { citations } \\
\end{array}$ & $\begin{array}{l}\text { Entire period: 1990-2015 } \\
\text { Jounal } \\
\end{array}$ & & $\begin{array}{r}\% \\
\text { citations } \\
\end{array}$ \\
\hline HARVARD BUS REV & 57 & $4,0 \%$ & STRATEGIC MANAGE J & 565 & $4,7 \%$ & STRATEGIC MANAGE J & 658 & $3,6 \%$ & STRATEGIC MANAGE J & 1,264 & $4,1 \%$ \\
\hline STRATEGIC MANAGE J & 41 & $2,9 \%$ & MANAGE SCI & 459 & $4,0 \%$ & MANAGE SCI & 658 & $3,6 \%$ & MANAGE SCI & 1,144 & $3,7 \%$ \\
\hline ADMIN SCI QUART & 29 & $2,0 \%$ & RES POLICY & 366 & $3,2 \%$ & J OPER MANAG & 463 & $2,6 \%$ & RES POLICY & 781 & $2,5 \%$ \\
\hline MANAGE SCI & 27 & $1,9 \%$ & HARVARD BUS REV & 344 & $2,5 \%$ & ORGAN SCI & 411 & $2,3 \%$ & HARVARD BUS REV & 737 & $2,4 \%$ \\
\hline RES POLICY & 23 & $1,6 \%$ & ADMIN SCI QUART & 314 & $2,5 \%$ & RES POLICY & 392 & $2,2 \%$ & ORGAN SCI & 712 & $2,3 \%$ \\
\hline COMMUN ACM & 21 & $1,5 \%$ & ORGAN SCI & 286 & $2,3 \%$ & ACAD MANAGE REV & 350 & $1,9 \%$ & ADMIN SCI QUART & 663 & $2,1 \%$ \\
\hline ACAD MANAGE REV & 20 & $1,4 \%$ & ACAD MANAGE REV & 226 & $2,0 \%$ & HARVARD BUS REV & 336 & $1,9 \%$ & J OPER MANAG & 626 & $2,0 \%$ \\
\hline IEEE T SOFTWARE ENG & 17 & $1,2 \%$ & ACAD MANAGE $\mathbf{J}$ & 168 & $1,5 \%$ & ADMIN SCI QUART & 320 & $1,8 \%$ & ACAD MANAGE REV & 596 & $1,9 \%$ \\
\hline ORGAN SCI & 15 & $1,1 \%$ & J OPER MANAG & 159 & $1,1 \%$ & J PROD INNOVAT MANAG & 277 & $1,5 \%$ & $\begin{array}{l}\text { ACAD MANAGE J } \\
\text { J PROD INNOVAT }\end{array}$ & 428 & $1,4 \%$ \\
\hline INT J PROD RES & 14 & $1,0 \%$ & $\begin{array}{l}\text { IND CORP CHANGE } \\
\text { J PROD INNOVAT }\end{array}$ & 130 & $1,0 \%$ & INT J OPER PROD MAN & 275 & $1,5 \%$ & MANAG & 397 & $1,3 \%$ \\
\hline SLOAN MANAGE REV & 13 & $0,9 \%$ & MANAG & 119 & $1,0 \%$ & INT J PROD ECON & 250 & $1,4 \%$ & IND CORP CHANGE & 376 & $1,2 \%$ \\
\hline ACAD MANAGE $\mathbf{J}$ & 13 & $0,9 \%$ & INT J PROD RES & 107 & $0,9 \%$ & ACAD MANAGE $\mathbf{J}$ & 247 & $1,4 \%$ & INT J OPER PROD MAN & 366 & $1,2 \%$ \\
\hline CALIF MANAGE REV & 13 & $0,9 \%$ & SLOAN MANAGE REV & 106 & $0,9 \%$ & IND CORP CHANGE & 245 & $1,3 \%$ & INT J PROD RES & 351 & $1,1 \%$ \\
\hline OPER RES & 10 & $0,7 \%$ & EUR J OPER RES & 97 & $0,8 \%$ & INT J PROD RES & 230 & $1,3 \%$ & INT J PROD ECON & 339 & $1,1 \%$ \\
\hline J MANAGEMENT INFORMA & 9 & $0,6 \%$ & IEEE T ENG MANAGE & 88 & $0,8 \%$ & IEEE T ENG MANAGE & 187 & $1,0 \%$ & IEEE T ENG MANAGE & 283 & $0,9 \%$ \\
\hline IEEE T ENG MANAGE & 8 & $0,6 \%$ & J MARKETING & 87 & $0,8 \%$ & EUR J OPER RES & 122 & $0,7 \%$ & EUR J OPER RES & 227 & $0,7 \%$ \\
\hline MATH PROGRAM & 8 & $0,6 \%$ & INT J OPER PROD MAN & 87 & $0,8 \%$ & DECISION SCI & 121 & $0,7 \%$ & SLOAN MANAGE REV & 211 & $0,7 \%$ \\
\hline MIS QUART & 8 & $0,6 \%$ & INT J PROD ECON & 87 & $0,8 \%$ & MIS QUART & 119 & $0,7 \%$ & J MARKETING & 176 & $0,6 \%$ \\
\hline ARTIF INTELL & 8 & $0,6 \%$ & CALIF MANAGE REV & 79 & $0,6 \%$ & PROD OPER MANAG & 106 & $0,6 \%$ & MIS QUART & 170 & $0,5 \%$ \\
\hline EUR J OPER RES & 8 & $0,6 \%$ & AM ECON REV & 68 & $0,6 \%$ & J ECON BEHAV ORGAN & 93 & $0,5 \%$ & CALIF MANAGE REV & 167 & $0,5 \%$ \\
\hline Total references & $\begin{array}{r}1,4 \\
17 \\
\end{array}$ & & Total references & 11,434 & & Total references & 18,149 & & Total references & 31,000 & \\
\hline
\end{tabular}

Source: Citations to journals from source articles on modularity resulting from the literature search on modularity excluding self-references. 
Table IV. Factors identified through factor analysis

\begin{tabular}{clccc} 
Factor & Interpretation & Articles & Eigenvalue & \% of Variance \\
\hline 1 & Organizational integration and the boundaries of the firm & 14 & 6.7 & 9.8 \\
2 & Modular production and mass customization & 13 & 3.9 & 5.7 \\
3 & Component commonality & 4 & 2.9 & 4.3 \\
4 & Organizational search and adaptation & 8 & 2.6 & 3.8 \\
5 & Product architecture for flexibilty and substitution & 8 & 2.3 & 3.3 \\
6 & Service modularity the case of modular care provision & 3 & 2.1 & 3.2 \\
7 & Product architecture and modularity & 8 & 1.8 & 2.7 \\
8 & New product development & 5 & 1.8 & 2.6 \\
9 & Organizational capabilities & 5 & 1.5 & 2.3 \\
\hline Total & & $\mathbf{6 8}$ & & $\mathbf{3 7 . 7}$ \\
\hline
\end{tabular}


Table V. Source articles in the recent period co-citing seminal service modularity papers

\begin{tabular}{|c|c|c|c|c|}
\hline Reference & Title & $\begin{array}{l}\text { Voss \& } \\
\text { Hsuan } \\
(2009)\end{array}$ & $\begin{array}{c}\text { Pekkarinen } \\
\text { \& Ulkuniemi } \\
\text { (2008) }\end{array}$ & $\begin{array}{c}\text { Bask et al. } \\
(\mathbf{2 0 1 0})\end{array}$ \\
\hline Aas \& Pedersen (2013) & $\begin{array}{l}\text { The usefulness of componentization for specialized public service } \\
\text { providers } \\
\text { Modularity in KIBS: The Case of Third-Party Logistics Service }\end{array}$ & 1 & 1 & 1 \\
\hline Cabigiosu et al. (2015) & Providers & 1 & 1 & 1 \\
\hline de Blok et al. (2014) & $\begin{array}{l}\text { Interfaces in service modularity: A typology developed in } \\
\text { modular health care provision } \\
\text { Views of logistics service providers on modularity in logistics }\end{array}$ & 1 & 1 & 1 \\
\hline Rajahonka (2013) & services & 1 & 1 & 1 \\
\hline Vahatalo \& Kallio (2015) & Organising health services through modularity & 1 & 1 & 1 \\
\hline Bask et al. (2011) & $\begin{array}{l}\text { Framework for modularity and customization: service perspective } \\
\text { Developing a Modular Service Architecture for E-store Supply }\end{array}$ & & 1 & 1 \\
\hline Bask et al. (2014) & Chains: The Small- and Medium-Sized Enterprise Perspective & 1 & & 1 \\
\hline Carlborg \& Kindstrom (2014) & $\begin{array}{l}\text { Service process modularization and modular strategies } \\
\text { Modular care and service packages for independently living }\end{array}$ & & 1 & 1 \\
\hline de Blok et al. (2013) & for personalization and customization & 1 & 1 & \\
\hline Hellstrom (2014) & case of complex capital goods & 1 & & 1 \\
\hline Hofman \& Meijerink (2015) & Platform thinking for services: the case of human resources & 1 & 1 & \\
\hline Lin \& Pekkarinen (2011) & QFD-based modular logistics service design & 1 & 1 & \\
\hline \multicolumn{2}{|c|}{ Co-citations (total citations from modularity literature) } & $11(17)$ & $11(15)$ & $9(9)$ \\
\hline
\end{tabular}

Source: Based on bibliographic data from the literature search on modularity 
Table VI. Journals with source articles in the recent period co-citing seminal service modularity papers

\begin{tabular}{|c|c|c|c|c|}
\hline Reference & $\begin{array}{l}\text { Voss \& } \\
\text { Hsuan } \\
(2009)\end{array}$ & $\begin{array}{c}\text { Pekkarinen } \\
\& \\
\text { Ulkuniemi } \\
(\mathbf{2 0 0 8}) \\
\end{array}$ & $\begin{array}{c}\text { Bask et al. } \\
(2010)\end{array}$ & Total \\
\hline JOURNAL OF BUSINESS \& INDUSTRIAL MARKETING & 1 & 5 & 2 & 8 \\
\hline INTERNATIONAL JOURNAL OF OPERATIONS \& PRODUCTION MANAGEMENT & 4 & 2 & 1 & 7 \\
\hline INDUSTRY AND INNOVATION & 1 & 1 & 1 & 3 \\
\hline INTERNATIONAL JOURNAL OF LOGISTICS-RESEARCH AND APPLICATIONS & 1 & 1 & 1 & 3 \\
\hline JOURNAL OF OPERATIONS MANAGEMENT & 1 & 1 & 1 & 3 \\
\hline MANAGING SERVICE QUALITY & 1 & 1 & 1 & 3 \\
\hline INTERNATIONAL JOURNAL OF PRODUCTION ECONOMICS & 1 & 1 & & 2 \\
\hline JOURNAL OF SERVICE MANAGEMENT & 1 & & 1 & 2 \\
\hline SERVICE INDUSTRIES JOURNAL & 1 & 1 & & 2 \\
\hline SERVICE SCIENCE & 1 & & 1 & 2 \\
\hline CONCURRENT ENGINEERING-RESEARCH AND APPLICATIONS & & 1 & & 1 \\
\hline DECISION SCIENCES & 1 & & & 1 \\
\hline INTERNATIONAL JOURNAL OF PRODUCTION RESEARCH & 1 & & & 1 \\
\hline R \& D MANAGEMENT & 1 & & & 1 \\
\hline TECHNOLOGICAL FORECASTING AND SOCIAL CHANGE & & 1 & & 1 \\
\hline TECHNOVATION & 1 & & & 1 \\
\hline Total & 17 & 15 & 9 & 41 \\
\hline
\end{tabular}

Source: Based on bibliographic data from the literature search on modularity 
Appendix I. Seminal contributions within the modularity literature

Reference*
Sanchez and Mahoney (1996) Management in product modularity, flexibility, and
knowledge organization design (SMJ)
knowledge organization design (SMJ)

Baldwin and Clark (1997) Managing in an age of modularity (HBR)

Schilling (2000) Toward a general modular systems theory and its application to inter-firm product modularity (AMR)

Schilling and Steensma (2001) The use of modular organizational forms: An industry-level analysis (AMJ)

Ethiraj and Levinthal (2004) Modularity and innovation in complex systems (MS)

Garud and Kumaraswamy (1995) Technological and organizational designs for realizing economies of substitution (SMJ)

Langlois (2002) Modularity in technology and organization (JEBO)

Sanchez (1995) Strategic flexibility in product competition (SMJ)

Salvador et al. (2002) Modularity, product variety, production volume, and component sourcing: theorizing beyond generic prescriptions (JOM)

Duray et al. (2000) Approaches to mass customization: configurations and empirical validation (JOM)

Sanchez (1999) Modular architectures in the marketing process (JM)

Mikkola and Gassmann (2003) Managing modularity of product architectures: Toward an integrated theory (IEEE TEM)

Worren et al. (2002) Modularity, strategic flexibility, and firm performance: A study of the home appliance industry (SMJ)

Baldwin (2008) Where do transactions come from? Modularity, transactions, and the boundaries of firms (ICC)

Hoetker (2006) Do modular products lead to modular organizations? (SMJ)

Sosa et al. (2004) The misalignment of product architecture and organizational structure in complex product development (MS)

Mikkola (2003) Modularity, component outsourcing, and inter-firm learning (R\&D $\mathrm{M})$

Salvador (2007) Toward a product system modularity construct: Literature review and reconceptualization (IEE TEM)

Pil and Cohen (2006) Modularity: Implications for imitation, innovation, and sustained advantage (AMR)

Tu et al. (2004) Measuring modularity-based manufacturing practices and their impact on mass customization capability: A customer-driven perspetive (DS)

40

Theoretical Perspective

Object of modularity

$204 \quad$ Conceptual

Strategic Management

141 Conceptual with illustrative cases

140 General Theory development

64 Test of model using data from 330 manufacturing industries in the US

60 Conceptual with NK simulation model

60 Conceptual

57 Conceptual - developing a modularity theory of

the firm

52 Conceptual

$47 \quad$ Multiple case studies (six product families)

42 Configuration model to classify mass customizers with empirical validation

40 Conceptual with reference to cases in the

literature

Modelling (modularization function) with
illustrative case (Schindler elevators)

illustrative case (Schindler elevators)
Conceptual model tested with SEM model (data

from managers in home appliance comp.)

Develop theoretical framework

Causal model (empirical)

Case study (large commercial aircraft engine

development process)

Case study (Chrysler Jeep WIPER)

30 Literature review

31 Develop theoretical framework

28 Empirical survey ( $\mathrm{n}=303$, LISREL to estimate structural relations)
Strategic Management

General theory of modular systems Products and General

General theory of modular systems

Complex Adaptive Systems

Strategic Management

Organizational Economic

Strategic Management

Managerial/Engineering

Engineering

Strategic/Marketing Management

Engineering/Management

Management

Economic

Economic

Engineering/Organizational

Engineering/Organizational

Engineering/Management

Management/Organizational

Engineering/Organizational/

Management
Products and organization

Products and processes

systems

Organization

Decision variables

Technological systems

Organization

Products

Products

Products

Product, processes and

knowledg

Products

Products

Organization

Products and organization

Products

Product

Products, processes and design practices

Products and manufacturing processes
Products and organization

*Academy of Management Journal (AMJ), Academy of Management Review (AMR), Decision Sciences (DS), Harvard Business Review (HBR), IEEE Transactions on Engineering Management (IEEE TEM), Journal of Economic Behavior and Organization (JEBO), Journal of Marketing (JM), Journal of Operations Management (JOM), Management Science (MS), R and D Management (R\&DM), Research Policy (RP), Strategic Management Journal (SMJ), Industrial and Corporate Change (ICC)

** Number of citations from articles identified in the bibliographic search on modularity described in section 3. Self references are excluded. 
Appendix II . Seminal articles in journals most frequently cited by papers on modularity

\begin{tabular}{|c|c|c|c|c|c|c|c|c|c|c|c|}
\hline \multirow[b]{2}{*}{ Journal } & \multicolumn{3}{|c|}{ Citations by modularity literature } & \multicolumn{3}{|l|}{ Most cited reference in journal } & \multicolumn{3}{|c|}{ Modularity literature in journal } & \multicolumn{2}{|c|}{ Journal self references (\% of) } \\
\hline & Citations & Articles & Average & Reference & Citations & $\%$ of all & Articles & References & To journal & Citations & References \\
\hline STRATEGIC MANAGE J & 1.264 & 364 & 3,5 & Sanchez R, 1996, V17, P63 & 204 & $16,1 \%$ & 16 & 1.076 & 119 & $9,4 \%$ & $11,1 \%$ \\
\hline MANAGE SCI & 1.144 & 386 & 3,0 & Ethiraj SK, 2004, V50, P159 & 60 & $5,2 \%$ & 19 & 798 & 76 & $6,6 \%$ & $9,5 \%$ \\
\hline RES POLICY & 781 & 204 & 3,8 & Ulrich K, 1995, V24, P419 & 167 & $21,4 \%$ & 17 & 1.094 & 104 & $13,3 \%$ & $9,5 \%$ \\
\hline HARVARD BUS REV & 737 & 250 & 2,9 & Baldwin CY, 1997, V75, P84 & 140 & $19,0 \%$ & 1 & 12 & 0 & $0,0 \%$ & $0,0 \%$ \\
\hline ORGAN SCI & 712 & 284 & 2,5 & Kogut B, 1992, V3, P383 & 25 & $3,5 \%$ & 18 & 1.363 & 95 & $13,3 \%$ & $7,0 \%$ \\
\hline ADMIN SCI QUART & 663 & 161 & 4,1 & Henderson RM, 1990, V35, P9 & 135 & $20,4 \%$ & 2 & 124 & 13 & $2,0 \%$ & $10,5 \%$ \\
\hline J OPER MANAG & 626 & 252 & 2,5 & Salvador F, 2002, V20, P549 & 47 & $7,5 \%$ & 11 & 656 & 46 & $7,3 \%$ & $7,0 \%$ \\
\hline ACAD MANAGE REV & 596 & 183 & 3,3 & Schilling MA, 2000, V25, P312 & 140 & $23,5 \%$ & 4 & 393 & 24 & $4,0 \%$ & $6,1 \%$ \\
\hline ACAD MANAGE J & 428 & 204 & 2,1 & Schilling MA, 2001, V44, P1149 & 64 & $15,0 \%$ & 1 & 98 & 0 & $0,0 \%$ & $0,0 \%$ \\
\hline J PROD INNOVAT MANAG & 397 & 179 & 2,2 & Mikkola JH, 2006, V23, P128 & 26 & $6,5 \%$ & 15 & 922 & 55 & $13,9 \%$ & $6,0 \%$ \\
\hline IND CORP CHANGE & 376 & 107 & 3,5 & Brusoni S, 2001, V10, P179 & 55 & $14,6 \%$ & 7 & 563 & 38 & $10,1 \%$ & $6,7 \%$ \\
\hline INT J OPER PROD MAN & 366 & 167 & 2,2 & Jacobs M, 2007, V27, P1046 & 22 & $6,0 \%$ & 51 & 1.896 & 136 & $37,2 \%$ & $7,2 \%$ \\
\hline INT J PROD RES & 351 & 288 & 1,2 & Agard B, 2004, V42, P2955 & 5 & $1,4 \%$ & 51 & 1.830 & 175 & $49,9 \%$ & $9,6 \%$ \\
\hline INT J PROD ECON & 339 & 228 & 1,5 & Muffatto M, 1999, V60-1, P145 & 12 & $3,5 \%$ & 30 & 1.853 & 139 & $41,0 \%$ & $7,5 \%$ \\
\hline IEEE T ENG MANAGE & 283 & 105 & 2,7 & Mikkola JH, 2003, V50, P204 & 40 & $14,1 \%$ & 24 & 1.282 & 52 & $18,4 \%$ & $4,1 \%$ \\
\hline EUR J OPER RES & 227 & 160 & 1,4 & Kim K, 2000, V125, P602 & 16 & $7,0 \%$ & 11 & 307 & 20 & $8,8 \%$ & $6,5 \%$ \\
\hline SLOAN MANAGE REV & 211 & 77 & 2,7 & Robertson D, 1998, V39, P19 & 45 & $21,3 \%$ & 1 & 10 & 0 & $0,0 \%$ & $0,0 \%$ \\
\hline J MARKETING & 176 & 96 & 1,8 & Sanchez R, 1999, V63, P92 & 40 & $22,7 \%$ & 1 & 23 & 0 & $0,0 \%$ & $0,0 \%$ \\
\hline MIS QUART & 170 & 121 & 1,4 & Rai A, 2006, V30, P225 & 5 & $2,9 \%$ & 2 & 179 & 11 & $6,5 \%$ & $6,1 \%$ \\
\hline CALIF MANAGE REV & 167 & 102 & 1,6 & Thomke S, 1998, V41, P8 & 9 & $5,4 \%$ & 6 & 220 & 14 & $8,4 \%$ & $6,4 \%$ \\
\hline Total & 31.000 & 18.409 & 1,7 & & & & 636 & 31.000 & 1.708 & $5,5 \%$ & $5,5 \%$ \\
\hline
\end{tabular}

Source: Citations to journals from source articles on modularity resulting from the literature search on modularity excluding self-references. 

initiatives in the global automotive industry

Campagnolo \& Camuffo (2010) INT J MANAG

Kapoor (2013) ORGAN SCI

Ulku \& Schmidt (2011) PROD OPER MANAG

Cabigiosu \& Camuffo (2012) ORGAN SCI

Baldwin (2008) IND CORP CHANGE

Fixson \& Park (2008) RES POLICY

Park \& Ro (2011) J OPER MANAG

Cabigiosu et al. (2013) RES POLICY

Zirpoli \& Becker (2011b) R\&D MANAGE

Hoetker (2006) STRATEG MANAGE J

Caridi et al. (2012) INT J PROD ECON

Jacobides \& Billinger (2006) ORGAN SCI

Murmann \& Frenken (2006) RES POLICY

2: Modular production and mass customization

Jacobs et al. (2011) J PROD INNOVAT MANAGE

Tu et al. (2004) DECISION SCI

Jacobs et al. (2007) INT J OPER PROD MANAGE

Droge et al. (2012) INT J PROD ECON

Salvador et al. (2004) PRODUCTION PLANNING CONTROL

Peng et al. (2011) INT J OPER PROD MAN

Antonio et al. (2007) INT J PROD ECON

Mikkola (2007) IEEE TRANS ENG MANAGE

Salvador et al. (2002) J OPER MANAG

Lau, Yam \& Tang (2010) INT J OPER PROD

MANAGE

Lau et al. (2011) J PROD INNOVAT MANAG

Lau (2011) J ENG TECHNOL MANAGE

Terjesen et al. (2012) DECISION SCI

3: Component commonality

Zhang et al. (2008) INT J PROD RES

Zhang \& Huang (2010) INT J PROD ECON

Huang et al. (2007) IEEE TRANS ENG MANAGE

Huang et al. (2005) J OPER MANAG

4: Organizational search and adaptation

Siggelkow \& Rivkin (2005) ORGAN SCI

Siggelkow \& Levinthal (2003) ORGAN SCI

Ethiraj \& Levinthal (2004a) ADMIN SCI QUART

Sinha \& Van de Ven (2005) ORGAN SCI

Yayavaram \& Ahuja (2008) ADMIN SCI QUART

Zhou (2013) ORGAN SCI

Fleming \& Sorenson (2001a) RES POLICY

Pil \& Cohen (2006) ACAD MANAGE REV

5: Product architecture for flexibilty and substitution Sanchez \& Mahoney (1996) STRATEG MANAGE $\mathrm{J}$

Sanchez (2000) INT J TECHNOL MANAGE

Sanchez (1995) STRATEG MANAGE J

Garud \& Kumaraswamy (1995) STRATEG

MANAGE J

Mikkola (2003) R D MANAGE

Mikkola (2006) J PROD INNOVAT MANAGE

Cebon et al. (2008) INT J TECHNOL MANAGE

Karim (2006) STRATEG MANAGE J

6: Service modularity the case of modular care

provision

de Blok et al. (2013) INT J PROD ECON

de Blok et al. (2010) INT J OPER PROD

MANAGE

de Blok et al. (2014) J OPER MANAG

7: Product architecture and platforms

Salvador (2007) IEEE TRANS ENG MANAGE

Kong et al. (2009) CONCURRENT ENG-

RESEARCH APPL

The Concept of Modularity in Management Studies: A Literature Review

Persistence of Integration in the Face of Specialization: How Firms Navigated the Winds of Disintegration and Shaped the Architecture of the Semiconductor Industry

Matching Product Architecture and Supply Chain Configuration

Beyond the "Mirroring" Hypothesis: Product Modularity and Interorganizational Relations in the Air Conditioning Industry

Where do transactions come from? Modularity, transactions, and the boundaries of firms

The power of integrality: Linkages between product architecture, innovation, and industry structure

The impact of a firm's make, pseudo-make, or buy strategy on product performance

Modularity, interfaces definition and the integration of external sources of innovation in the automotive industry

The limits of design and engineering outsourcing: performance integration and the unfulfilled promises of modularity

Do modular products lead to modular organizations?

Linking product modularity and innovativeness to supply chain management in the Italian furniture industry

Designing the boundaries of the firm: From "make, buy, or ally" to the dynamic benefits of vertical architecture

Toward a systematic framework for research on dominant designs, technological innovations, and industrial change

0,565

0,534

0,526

0,526

0,515

0,511

0,488

0,421

0,382

0,355

0,347

0,293

Product and Process Modularity's Effects on Manufacturing Agility and Firm Growth Performance

Measuring modularity-based manufacturing practices and their impact on mass customization capability: A customer-driven perspective

The effects of product modularity on competitive performance - Do integration strategies mediate the relationship? Does supply chain integration mediate the relationships between product/process strategy and service performance? An empirical study

Supply-chain configurations for mass customization

Impacts of information technology on mass customization capability of manufacturing plants The impacts of product modularity on competitive capabilities and performance: An empirical study

Management of product architecture modularity for mass customization: Modeling and theoretical considerations

Modularity, product variety, production volume, and component sourcing: theorizing beyond generic prescriptions

Supply chain integration and product modularity An empirical study of product performance for selected Hong Kong manufacturing industries

The Impact of Product Modularity on New Product Performance: Mediation by Product Innovativeness

Critical success factors in managing modular production design: Six company case studies in Hong Kong, China, and Singapore

Managing Differentiation-Integration Duality in Supply Chain Integration

Simultaneous configuration of platform products and manufacturing supply chains

Game-theoretic approach to simultaneous configuration of platform products and supply chains with one manufacturing firm and multiple cooperative suppliers

Integrated configuration of platform products and supply chains for mass customization: A game-theoretic approach Towards integrated optimal configuration of platform products, manufacturing processes, and supply chains

0,844

0,834

0,825

0,817

Speed and search: Designing organizations for turbulence and complexity

Temporarily divide to conquer: Centralized, decentralized, and reintegrated organizational approaches to exploration and adaptation

Bounded rationality and the search for organizational architecture: An evolutionary perspective on the design of organizations and their evolvability

Designing work within and between organizations

Decomposability in knowledge structures and its impact on the usefulness of inventions and knowledge-base malleability

Designing for Complexity: Using Divisions and Hierarchy to Manage Complex Tasks

Technology as a complex adaptive system: evidence from patent data

Modularity: Implications for imitation, innovation, and sustained advantage

Modularity, flexibility, and knowledge management in product and organization design

Modular architectures, knowledge assets and organizational learning: new management processes for product creation

Strategic flexibility in product competition

Technological and organizational designs for realizing economies of substitution

Modularity, component outsourcing, and inter-firm learning

Capturing the degree of modularity embedded in product architectures

Product modularity and the product life cycle: new dynamics in the interactions of product and process technologies

The human dimension of modular care provision: Opportunities for personalization and customization

Modular care and service packages for independently living elderly 
Fixson (2007) CONCURRENT ENG-RESEARCH Modularity and commonality research: past developments and future opportunities

APPL

Parmigiani \& Mitchell (2009) STRATEG

MANAGE J

Complementarity, capabilities, and the boundaries of the firm: the impact of within-firm and interfirm expertise on

Mikkola \& Gassmann (2003) IEEE TRANS ENG concurrent sourcing of complementary components

Managing modularity of product architectures: Toward an integrated theory

MANAGE

Yassine \& Wissmann (2007) SYST ENG

Fixson (2005) J OPER MANAG

Buganza \& Verganti (2006) J PROD INNOVAT

The implications of product architecture on the firm

0,394

Product architecture assessment: a tool to link product, process, and supply chain design decisions

0,313 MANAGE

8: New product development

Danese \& Filippini (2010) INT J OPER PROD

MANAGE

Life-cycle flexibility: How to measure and improve the innovative capability in turbulent environments

0,248

Modularity and the impact on new product development time performance Investigating the moderating effects of supplier involvement and interfunctional integration

Danese \& Filippini (2013) IEEE T ENG MANAGE

Salvador \& Villena (2013) J SUPPLY CHAIN

MANAG

Hong \& Hartley (2011) J SUPPLY CHAIN

MANAG

Pero et al. (2010) SUPPLY CHAIN MANAG

9: Organizational capabilities

Lei (2000) INT J TECHNOL MANAGE

Lei (2003) INT J TECHNOL MANAGE

Lei et al. (1996) ORGAN STUD

Martin \& Eisenhardt (2004) ADV STRAT M

Direct and Mediated Effects of Product Modularity on Development Time and Product Performance

0,609

Supplier Integration and NPD Outcomes: Conditional Moderation Effects of Modular Design Competence

Managing the supplier-supplier interface in product development: the moderating role of technological newness

A framework for the alignment of new product development and supply chains

Industry evolution and competence development: the imperatives of technological convergence

0,792

Competition, cooperation and learning: the new dynamics of strategy and organisation design for the innovation net

Advanced manufacturing technology: Organizational design and strategic flexibility

Coping with decline in dynamic markets: Corporate entrepreneurship and the recombinative organizational form

0,287

Schilling \& Steensma (2001) ACAD MANAGE J

The use of modular organizational forms: An industry-level analysis

0,287 